\title{
Petrografia e textura do pluton granitoide pós-colisional Serra da Macambira, Neoproterozoico da Província Borborema (Nordeste do Brasil)
}

\author{
Dalton Rosemberg Valentim da Silva ${ }^{1}$, Zorano Sérgio de Souza ${ }^{1 *}$
}

\begin{abstract}
Resumo O pluton Serra da Macambira faz parte do extenso magmatismo neoproterozoico que marca o final da orogênese Brasiliana/Pan-Africana na Província Borborema, sendo, aqui, objeto de caracterização geológica, petrográfica e textural. Está localizado no Estado do Rio Grande do Norte, encaixado em ortognaisses paleoproterozoicos (Complexo Caicó) e metassupracrustais neoproterozoicas (Grupo Seridó), na porção setentrional da Província Borborema, Nordeste do Brasil. As rochas que o compõem foram classificadas na seguinte sequência: enclaves de quartzo monzonito e biotita tonalito; monzogranitos porfiríticos; granitos equigranulares; diques tardios de granitos, microgranitos, pegmatitos, granófiros e aplitos. Relações de campo mostram que os granitos porfiríticos e enclaves microgranulares quartzo monzoníticos representam coexistência de magmas granítico e diorítico ou gabróide, ambos precoces em relação ao granito equigranular. A biotita é o máfico predominante nas rochas de todo o pluton. Sua cristalização em estágio magmático precoce, juntamente com hornblenda, indica que os magmas progenitores eram subsaturados em água (conteúdos iniciais entre 2 e 4\%). A zonação composicional no plagioclásio pode refletir o predomínio da cristalização fracionada, porém não se pode descartar a influência de processos de mistura de magma na composição do líquido. Diques ácidos tardios apresentam texturas granofírica e aplítica, caracterizando cristalização em condições hipabissais ou súbita perda de voláteis. Texturas ígneas preservadas, ausência ou fraca atuação de eventos tectônicos, associação de enclaves microgranulares intermediários a máficos e a consistência das amostras com o trend da série magmática monzonítica e/ou cálcio-alcalina de alto K em diagramas de composição modal são encontradas em complexos magmáticos pós-colisionais a pós-orogênicos descritos na literatura.
\end{abstract}

Palavras-chave: magmatismo; neoproteozoico; Província Borborema; texturas ígneas.

\begin{abstract}
Petrography and texture of the Serra da Macambira pluton, Neoproterozoic of Borborema Province (Northeast Brazil). The Serra da Macambira pluton is part of the large granitic magmatism which marks the final stage of the Brasiliano/Pan-African orogeny in the Borborema Province, being here subject of geological, petrographic and textural studies. The pluton is located on Rio Grande do Norte State, intrusive into Paleoproterozoic orthogneisses of the Caicó Complex and Neoproterozoic metassupracrustals of the Seridó Group, northern portion of the Borborema Province, Brazilian Northern. Based upon intrusion/inclusion field relationships, mineralogy and texture, the rocks of the pluton are classified as follows: microgranular intermediate enclaves (quartz-bearing monzonite and biotite-bearing tonalite), porphyritic monzogranite, equigranular sienogranite to monzogranite, and late granite, pegmatite and aplite dykes. Field relations show that the porphyritic granites and quartz-monzonites represent mingling of granitic and dioritic or gabbroic magmas, and are slightly older than the equigranular granites. Biotite is the main mafic phase, formed on earlier magmatic stage, together with hornblende, which indicates that the parental magma was water subsaturated. Textural relations and mineral zonation (mainly in plagioclase, as well as in zircon) indicate that the fractional crystallization was the main differentiation mechanism; otherwise, magma mingling could also modify the liquid composition and affect plagioclase crystallization. Late acidic dykes show granophiric and aplitic textures, which characterizes hypabyssal conditions of crystallization. Preserved igneous textures, absence or weak registration of ductile tectonics, association with mafic to intermediate enclaves and the consistence of samples with the trend of the monzonitic to high-K calcic-alkaline series all indicates post-collisional to post-orogenic complexes described on literature.
\end{abstract}

Keywords: magmatism; neoproterozoic; Borborema Province; igneous textures.

\section{INTRODUÇÃO Nas últimas décadas, a in-} terpretação da gênese e evolução de corpos ígneos tem se baseado usualmente em dados geocronológicos e geoquímicos. Todavia, uma retrospectiva histórica revela que estudos texturais e petrográficos, com o uso extensivo do microscópio no início do século 19, levaram à distinção de diferentes tipos de rochas e à definição de províncias ígneas (revisão em Young 2003). O termo textura está relacionado à maneira como um mineral se relaciona com os demais 
ao seu redor, considerando fatores como grau de cristalinidade, tamanho, forma e relações mútuas com outros cristais e/ou vidro, quando presentes. As revisões dos fatores mais relevantes na formação de texturas nas rochas ígneas podem ser vistas em Hibbard (1995), Winter (2001, cap. 3) e Vernon (2004, cap. 3). Ilustrações fotográficas de texturas são referidas a MacKenzie et al. (1982). Outras referências são adicionadas quando pertinente.

De acordo com Hibbard (1995), Winter (2001) e Vernon (2004), a formação de cristais a partir de um magma ocorre porque a solubilidade dos constituintes químicos do líquido diminui com a temperatura decrescente. Como os magmas silicatados são soluções complexas, os diversos componentes químicos atingem a saturação a diferentes temperaturas, o que leva à cristalização de minerais em diferentes estágios durante o resfriamento do magma e, por conseguinte, define a ordem de cristalização. Magmas também podem cristalizar em resposta à súbita perda de voláteis ou mudança de pressão. Mistura de magmas com diferentes temperaturas e conteúdo em voláteis e contaminação com fragmentos da encaixante e/ou xenocristais podem igualmente levar a instabilidades termais e composicionais e, portanto, ocasionar reabsorção, corrosão e mesmo fusão de minerais previamente formados, modificando a composição do magma residual e, assim, a ordem de cristalização.

A formação e o crescimento de cristais a partir de um líquido envolvem a nucleação e o crescimento do cristal, que dependem da difusão de componentes químicos por meio do meio circundante para e a partir da superfície de crescimento e da taxa de resfriamento do magma. A difusão é mais acentuada a maiores temperaturas, em magmas de menor viscosidade, ou seja, pobres em silício e ricos em voláteis. A combinação destes mecanismos é responsável pelas texturas encontradas nas rochas ígneas. A alta taxa (velocidade) de resfriamento favorece o surgimento de numerosos núcleos, não permitindo o crescimento de grãos, resultando em rochas de textura fina (a matriz de rochas vulcânicas) ou mesmo vítrea. Outro importante fator que pode levar às texturas aplíticas ou ao crescimento exagerado de cristais nos pegmatitos é a súbita perda ou supersaturação em voláteis no magma (Vernon 2004, London 2009). Os voláteis, especialmente água, flúor, boro, carbonato e bicarbonato, além de fósforo e lítio, quebram as ligações Si-O, o que reduz a polimerização dos magmas silicatados, diminuindo sua viscosidade e aumentando a taxa de difusão iônica (revisão em Winter 2001, Vernon 2004, London 2009; ver também Thomas \& Davidson 2012, Nabelek et al. 2010).

Para a interpretação da evolução magmática, torna-se fundamental entender a sequência de cristalização (Hibbard 1995, Winter 2001, Vernon 2004). Em geral, inclusões minerais, cristais euédri$\cos$ e fenocristais são precoces. Esta afirmação deve ser, contudo, reavaliada em cada caso. Como exemplo, megacristais de K-feldspato comumente euédricos se formam tardiamente em rochas graníticas, evidenciados por frequentes inclusões de outros minerais como resultado de taxa de crescimento muito maior do que a taxa de nucleação daquele mineral na presença de uma fase volátil. Bordas irregulares, intersticiais, circundando núcleos euédricos, são evidências de que pelo menos suas bordas cristalizaram tardiamente. Durante o resfriamento do magma, nem sempre o equilíbrio químico é mantido, o que resulta na variação composicional de minerais, denominada zonação. Embora seja mais facilmente observada em escala microscópica em plagioclásio, anfibólio e piroxênios, é um fenômeno comum em outros minerais analisados por microssonda eletrônica (granada, olivina).

A zonação química normal evidencia processos de cristalização fracionada; por outro lado, a zonação inversa, com núcleos corroídos, reflete desequilíbrio químico por mecanismos de mistura de magmas, contaminação, correntes de convecção na câmara magmática ou aporte de novos pulsos de magmas quentes. Já casos de zonação oscilatória podem indicar flutuação do teor de $\mathrm{H}_{2} \mathrm{O}$ do magma. Algumas texturas, entre elas granofírica e gráfica, indicam colocação em níveis crustais rasos e se devem à súbita perda de água, levando à cristalização rápida e simultânea de quartzo e álcali-feldspato (Barker 1970, Smith 1974, Nascimento et al. 2002). Outras texturas indicativas de resfriamento a temperaturas pós-magmáticas são a diminuição de simetria do K-feldspato (monoclínica para triclínica) e exsoluções como a pertita (lamelas de albita em microclínio). Outras modificações minerais neste estágio incluem uralitização, biotitização, cloritização, sericitização e saussuritização.

O objetivo deste trabalho é descrever uma suíte de rochas plutônicas (o corpo Serra da Macambira, parte central do Estado do Rio Grande do Norte) do final do Neoproterozoico da Província Borborema, 
detalhando variações composicionais e feições petrográficas e texturais. Isto levará à caracterização do magmatismo granítico pós-colisional, comparando-o a tipos conhecidos na literatura, visando às interpretações de dados litogeoquímicos e isotópicos em fase de aquisição.

CONTEXTO GEOLÓGICO A área estudada está inserida na porção setentrional da Província Borborema (Almeida et al. 1981). Esta província compreende o embasamento arqueano a paleoproterozoico, que serve de substrato a faixas metassupracrustais dobradas e diversos corpos plutônicos neoproterozoicos, em geral controlados por zonas de cisalhamento dúctil. A Faixa Seridó corresponde a uma sequência metassupracrustal, limitando-se a sul pelo Lineamento Patos, a oeste pela zona de cisalhamento Portalegre, e a norte e leste por coberturas sedimentares fanerozoicas (Jardim de Sá 1994, Van Schmus et al. 2003). As suítes plutônicas neoproterozoicas (Tab. 1) foram reagrupadas por Angelim et al. (2006) em Supersuíte sin- a tardi-orogênica (suítes São João do Sabugi, Itaporanga, Dona Inês, Catingueira) e Supersuíte pós-orogênica (Suíte Umarizal). Nascimento et al. (2008) utilizaram composições químicas e petrográficas para classificar estas suítes em shoshonítica, cálcio-alcalina potássica porfirítica, cálcio-alcalina potássica equigranular, alcalina e charnoquítica alcalina. Segundo Angelim et al. (2006), o pluton Serra da Macambira integra a Suíte Intrusiva Dona Inês (Fig. 1), constituída por monzogranitos a sienogranitos, equigranulares ou com variação a tipos microporfiríticos ou mesmo pegmatíticos, portando biotita e anfibólio ocasional (Angelim et al. 2006).
GEOLOGIA DO PLUTON SERRA DA MACAMBIRA A primeira etapa metodológica consistiu no levantamento de dados bibliográficos e cartográficos pré-existentes, seguida pelo processamento digital de produtos de sensoriamento remoto, que facilitou o desenvolvimento de mapas pré-campo em ambiente Sistema de Informações Geográficas (SIG). A segunda fase correspondeu aos trabalhos desenvolvidos em campo, onde foram analisados os aspectos mineralógicos, texturais, estruturais (foliações, lineações, juntas e falhas) e relações de contato.

O pluton Serra da Macambira está encaixado em ortognaisses bandados ou com textura augen, correlatos aos do embasamento paleoproterozoico (Complexo Caicó), biotita paragnaisses e rochas calciossilicáticas da Formação Jucurutu, e granada-biotita xistos da Formação Seridó (Fig. 2). Xenólitos de ortognaisses, paragnaisses, rochas calciossilicáticas e micaxistos são observados nos granitos equigranulares e porfiríticos que compõem o pluton. Arenitos cenozoicos (Formação Serra do Martins) formam platôs depositados sobre o pluton e seu embasamento. Nas bordas Sudeste e Sudoeste do pluton ocorrem plugs de basaltos relacionados ao magmatismo básico cenozoico (Souza et al. 2003, 2004).

O mapeamento das unidades litológicas permitiu identificar que a litologia predominante no pluton consiste em sienogranitos e monzogranitos equigranulares médios ou grossos, cuja distribuição espacial é ampla, abrangendo todo o pluton (Fig. 2). Monzogranitos porfiríticos ocorrem de maneira reduzida, como zonas e/ou corpos no interior do tipo dominante (equigranular), principalmente na borda sul. Enclaves microgranulares centimétricos de biotita tonalito são observados em granitos equigranulares e

Tabela 1 - Composição e idade das suites plutônicas neoproterozoicas e seu posicionamento com relação à orogenia Brasiliana/Pan-Africana

\begin{tabular}{|c|c|c|c|}
\hline Contexto & Suíte intrusiva & Composição & Idade U-Pb (Ma) \\
\hline & Pegmatitos e diques graníticos & $\begin{array}{l}\text { Pegmatitos e } \\
\text { diques graníticos }\end{array}$ & $\begin{array}{c}509,5 \pm 2,9^{\mathrm{a}} \\
514,9 \pm 1,1^{\mathrm{a}} \\
528 \pm 12^{\mathrm{a}}\end{array}$ \\
\hline $\begin{array}{l}\text { Pós- } \\
\text { orogênico }\end{array}$ & $\begin{array}{l}\text { Umarizal } \\
\text { (Alcalina charnoquítica) }\end{array}$ & Mangeritos e charnoquitos & $593 \pm 5^{b}$ \\
\hline \multirow{4}{*}{ 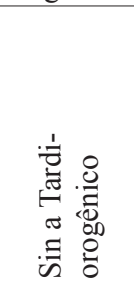 } & $\begin{array}{l}\text { Catingueira } \\
\text { (Alcalina) }\end{array}$ & Álcali-feldspato granitos e sienogranitos & $597 \pm 14^{\mathrm{c}}$ \\
\hline & $\begin{array}{l}\text { Dona Inês (Cálcio-alcalina de alto K, } \\
\text { equigranular) }\end{array}$ & $\begin{array}{l}\text { Monzogranitos (com menor ocorrência de } \\
\text { granodioritos e quartzo monzonitos) }\end{array}$ & $\begin{array}{l}541 \pm 4^{\mathrm{d}} \\
528 \pm 12^{\mathrm{a}}\end{array}$ \\
\hline & $\begin{array}{l}\text { Itaporanga (Cálcio-alcalina de alto K, } \\
\text { porfirítica) }\end{array}$ & Similar à suíte cálcio-alcalina de alto $\mathrm{K}$ equigranular & $\begin{array}{r}579,5 \pm 4^{\mathrm{e}} \\
555 \pm 5^{\mathrm{f}}\end{array}$ \\
\hline & São João do Sabugi (Shoshonítica) & Gabros/dioritos e quatzo-monzonitos & $579 \pm 7^{\mathrm{g}, \mathrm{h}}$ \\
\hline
\end{tabular}

a: Baumgartner et al. 2006; b: McReath et al. 2002; c: Souza et al. 2010; d: Medeiros et al. 2007; e: Trindade et al. 1999; f: Legrand et al. 1991; g: Leterrier et al. 1994; h: Jardim de Sá 1994.

Compilado de Angelim et al. 2006 e Nascimento et al. 2008. 


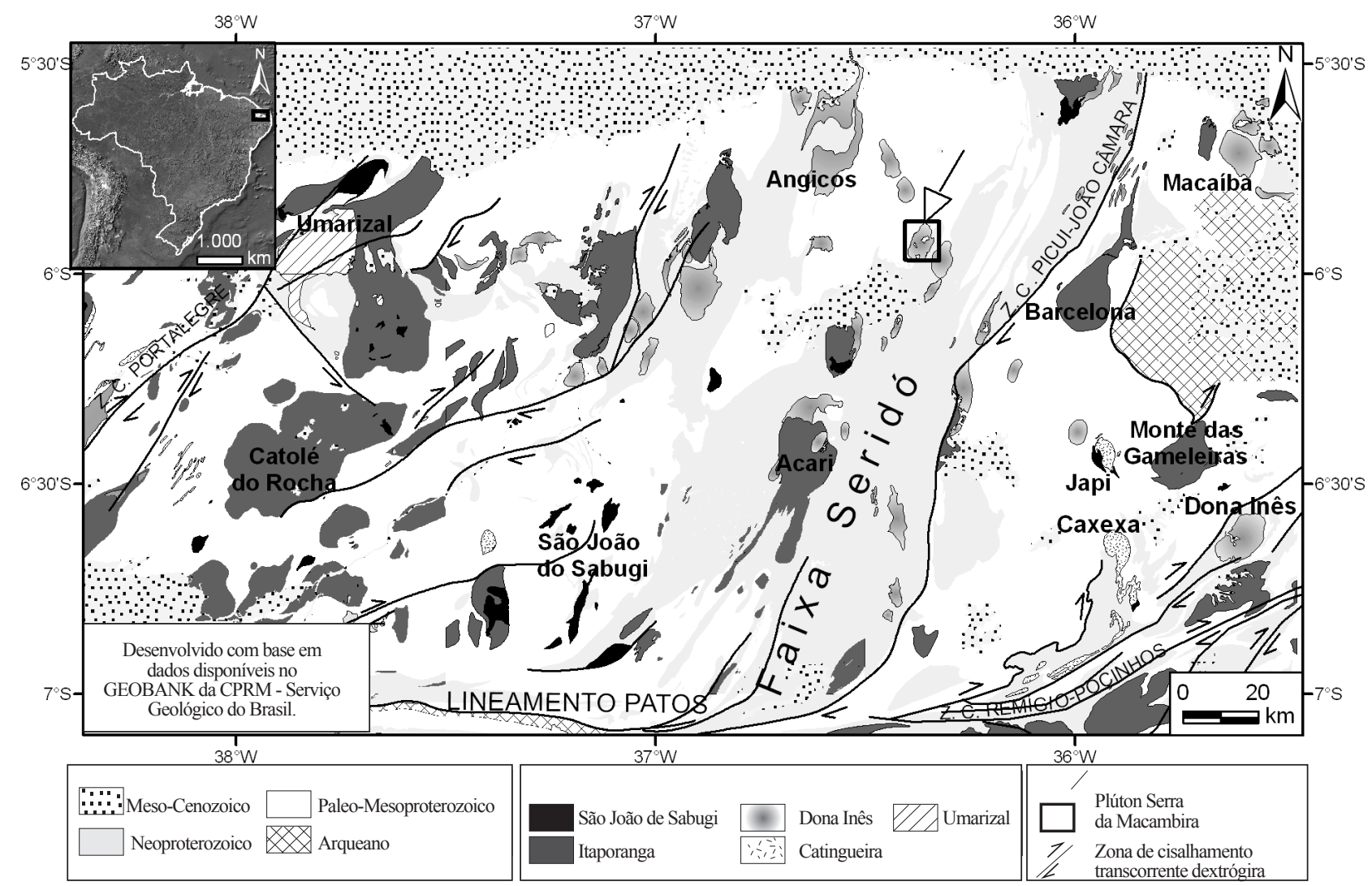

Figura 1 - Localização do pluton estudado no contexto geológico da Faixa Seridó, com ênfase nas diferentes suites plutônicas neoproterozoicas. Desenvolvido com base em dados do Geobank do Serviço Geológico do Brasil (acessado em 26 de novembro de 2010).
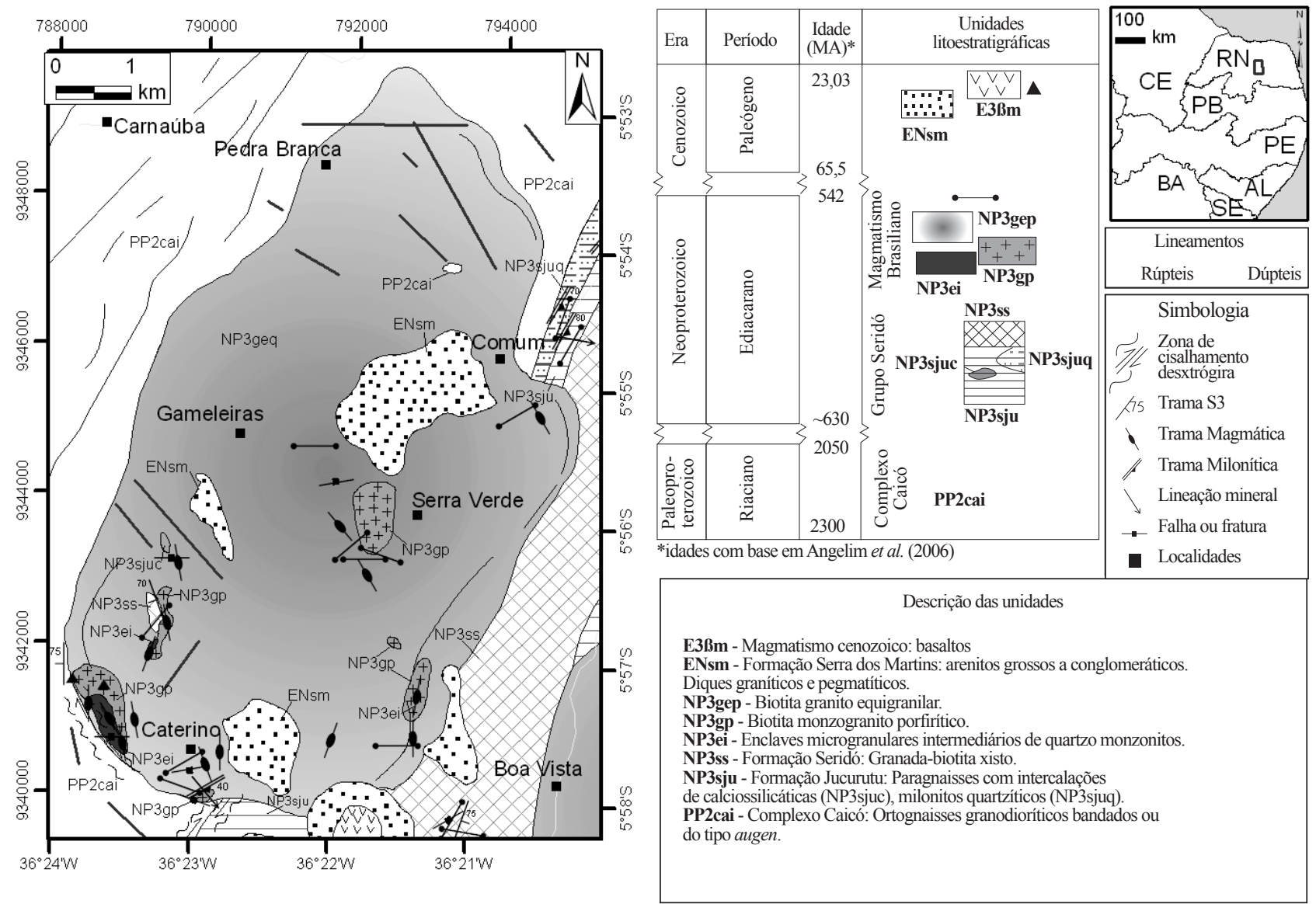

Figura 2 - Mapa geológico do pluton Serra da Macambira. 
porfiríticos ao longo de todo o pluton, enquanto que na sua borda sul encontra-se uma zona de concentração de enclaves microgranulares de quartzo monzonito, com dimensões métricas. Estes quartzo monzonitos stão associados ao monzogranito porfirítico, indicando a coexistência ou mistura de magmas. Os critérios de intrusão e inclusão observados em campo indicam que os granitos porfiríticos foram incluídos por um pulso magmático mais jovem, progenitor dos granitos equigranulares. $\mathrm{Na}$ borda sul do pluton o granito equigranular é observado intrudindo granito porfirítico e quartzo monzonito com contatos retilíneos e regulares. Diques (granitos, aplitos e pegmatíticos) tardios ao pulso magmático principal intrudem as demais rochas do pluton. Ao longo dele ocorre uma cobertura cenozoica, definida pelos arenitos da Formação Serra do Martins, e na borda sul acontecem plugs basálticos relacionados ao magmatismo básico cenozoico e, portanto, sem qualquer relação com o magmatismo neoproterozoico em tela.

A foliação observada nos granitos do interior do pluton é magmática (alinhamento de enclaves e de fenocristais euédricos de feldspatos), porém nas bordas Sudeste e Sudoeste esta foliação é superposta por tramas tectônicas (caudas de recristalização de feldspatos, reorientação de biotita e estiramento/recristalização de quartzo) associadas a discretas zonas de cisalhamento transcorrente dextrógiras de direções Nordeste e Noroeste. Na borda leste-sudeste e sul do pluton, o contato é abrupto, com o corpo ígneo truncando claramente a estrutura neoproterozoica, bem como as tramas em fácies anfibolito (cordierita \pm estaurolita \pm granada em micaxistos) do Grupo Seridó (Van Schmus et al. 2003). Aparentemente não se observam efeitos de contato sugestivos da profundidade de colocação; todavia, xenólitos angulosos de rochas metassupracrustais e gnaisses do embasamento cristalino permitem estimar um contraste de viscosidade relativamente alto ao tempo da intrusão e, consequentemente, nível crustal intermediário para o posicionamento final do corpo. Estas relações indicam que a colocação do pluton ocorreu subsequentemente ao pico do metamorfismo e da deformação regional (Neoproterozoico). A relação do plutonismo com a zona de cisalhamento foi interpretada como um exemplo dos processos observados por Weinberg et al. (2004), no qual a colocação do pluton gera condições para o desenvolvimento de zonas de cisalhamento dúcteis-rúpteis.

Enclaves microgranulares "Enclave" é uma denominação genérica aplicada a todo e qualquer agregado mineral ou poliminerálico incluído em rochas ígneas (revisão em Didier \& Barbarin 1991). Incluem xenólitos do material encaixante, autólitos (cumulatos fragmentados), xenocristais, enclaves micáceos (resíduos de fusão), enclaves félsicos (fragmentos félsicos de margens resfriadas) e enclaves microgranulares félsicos ou máficos (usualmente resultantes de processos de mistura de magmas).

No caso em estudo, as características descritas a seguir sugerem a presença de enclaves microgranulares félsicos a intermediários. Eles podem ser descritos considerando ora o predomínio do termo mais máfico (Fig. 3A), com feições indicativas de condições de resfriamento a maiores temperaturas, como por exemplo dissolução/corrosão de plagioclásio precoce, e outro com domínio do polo mais
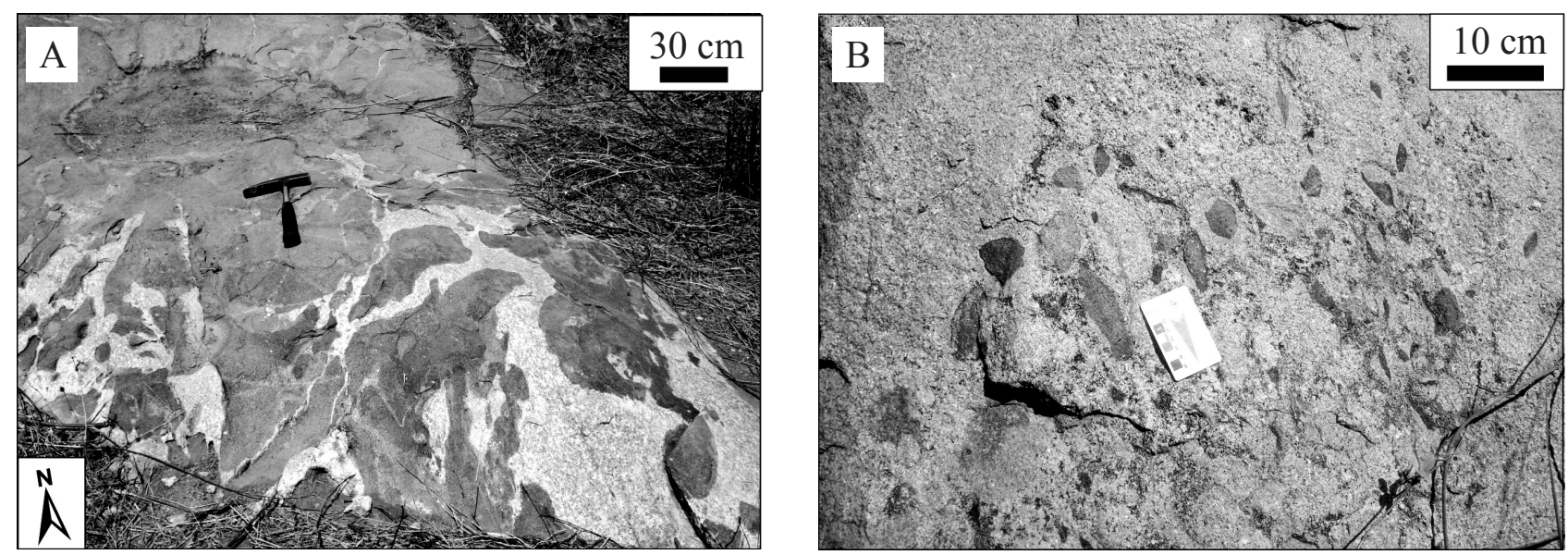

Figura 3 - (A) Aspecto de campo indicando coexistência entre magmas quartzo monzonítico (mais escuro) $e$ granítico, na porção Sudoeste do pluton, com predominância do pólo máfico; (B) Enclaves de biotita tonalitos (mais escuros) em granito equigranular na porção Sudeste do pluton, com predominância do pólo félsico. 
félsico (Fig. 3B), refletindo-se, inclusive, em texturas do tipo ocelo de quartzo. Os enclaves microgranulares de composição quartzo monzonítica observados no pluton estudado ocorrem como rochas mesocráticas a leucocráticas, cinza escuras, com dimensões decimétricas a métricas, frequentemente apresentando feições de coexistência com um componente ácido, granítico porfirítico (Fig. 3A). A localização dos quartzo monzonitos é restrita à borda sudoeste do pluton, na qual se observa a atuação de zona de cisalhamento transcorrente dextrógira, de direções NE e NW. Provavelmente em consequência da atuação desta zona de cisalhamento, os cristais de biotita e hornblenda nos quartzo monzonitos apresentam uma orientação preferencial. Esta localização restrita permite questionar se o quartzo monzonito seria de fato um enclave microgranular no sentido de Didier \& Barbarin (1991) ou representaria um magma intermediário levado a níveis crustais superiores em decorrência da atuação da zona de cisalhamento e posicionado como dique sinplutônico. Também ocorrem enclaves microgranulares centimétricos, arredondados a subarredondados de biotita tonalito com orientação preferencial indicativa de fluxo magmático (Fig. 3B). Estes estão distribuídos em granitos equigranulares e porfiríticos ao longo de todo o pluton.

\section{Biotita monzogranito porfirítico É caracte-} rizada pela presença de fenocristais de granulação grossa de K-feldspato em uma matriz fina (Fig. 4A). É frequente a associação destas rochas com tipos intermediários, evidenciando processos de coexistência de magmas, sendo ambos precoces com relação ao granito equigranular, que mostra relação intrusiva (Fig. 4B). Na borda sul do pluton, o granito porfirítico e o tipo equigranular apresentam evidências de deformação (Fig. 4C), sob influência de zona de cisalhamento transcorrente dextrógira, com direções NE-SW e NW-SE. Caudas de recristalização em $\mathrm{K}$-feldspato são as principais feições texturais que representam o cisalhamento dúctil transcorrente, mostrando que esta é uma zona de alta temperatura. A mesma figura evidencia a ação de juntas secas submeridianas, consideradas resultantes do soerguimento regional em alto nível crustal.

\section{Biotita sienogranito a monzogranito equigranu-} lar É o tipo de maior expressão superficial. Aflora como grandes lajedos de granito bege ou róseo,
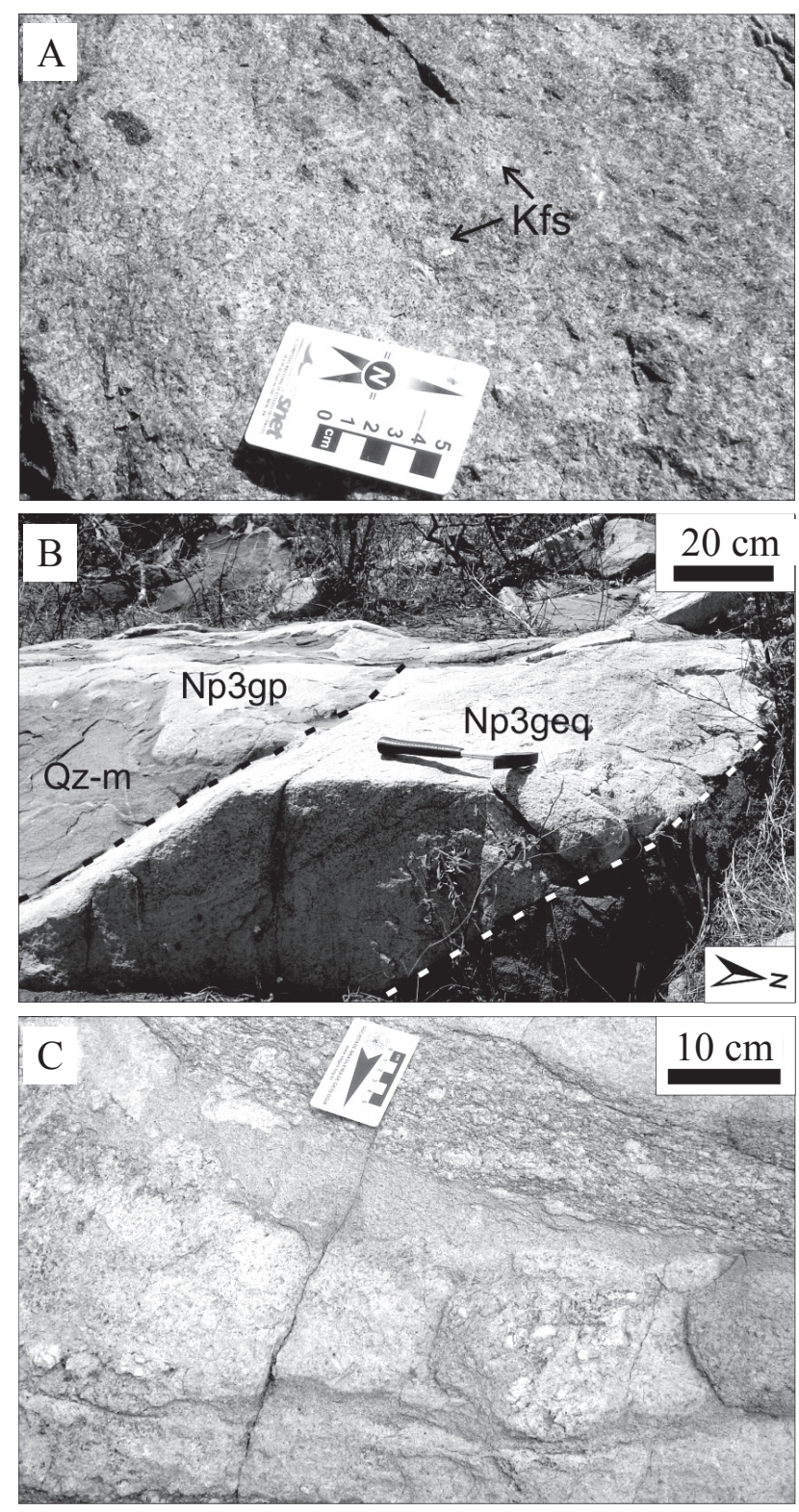

Figura 4 - (A) Monzogranito porfirítico com fenocristais de K-feldspato e enclaves de biotita tonalito, na porção leste do pluton; (B) Corpo granitico tabular, equigranular [NP3geq], intrusivo em granito porfirítico [NP3gp] e em quartzomonzonito $[Q z-m]$ (Sudoeste do pluton); (C) Granitos porfiritico e equigranular intensamente afetados por zona de cisalhamento dextrógira na borda Sudeste do pluton.

leucocrático a hololeucocrático. Macroscopicamente, são facilmente reconhecidos K-feldspato, plagioclásio, quartzo (por vezes avermelhado devido à oxidação) e biotita. Predomina a textura equigranular média ou grossa (Fig. 5). Enclaves microgranulares de biotita-tonalito ocorrem com orientação paralela à trama planar magmática (direcionada $330^{\circ} \mathrm{Az}$ ), além de xenólitos centimétricos a métricos de micaxisto, paragnaisse, rocha calciossilicática e ortognaisse (complexo de embasamento). 
Diques graníticos e pegmatitos São rochas hololeucocráticas, ocorrendo como diques graníticos finos róseos e pegmatitos brancos. Têm relações intrusivas com as demais litologias, evidenciando a colocação das mesmas na fase final de resfriamento do pluton. Diques pegmatíticos de direção ESE-WNW intrudem o granito equigranular, preservando contatos irregulares. A atitude dos diques indica extensão $\left(\sigma_{3}\right)$ na direção NNE-SSW (Fig. 6). Alguns pegmatitos apresentam textura gráfica, uma parte central composta de quartzo leitoso e bordas com maior quantidade de cristais de K-feldspato. A forma de ocorrência e a variação textura são sugestivas da ação de fluxo altamente silicoso residual supersaturado em voláteis percolando canais (fraturas), propiciando a

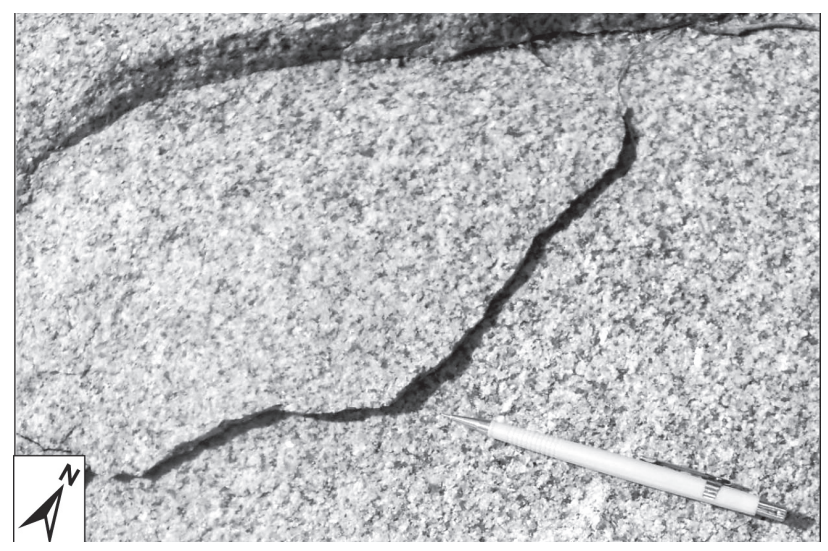

Figura 5-Biotita granito equigranular grosso (Sudeste do pluton), com orientação dimensional incipiente de cristais de biotita marcando o fluxo magmático. cristalização de megacristais de feldspatos, quartzo e turmalina (London 2009). A presença de voláteis baixa a viscosidade do líquido félsico, favorecendo a precipitação de magnetita por gravidade em um dos bordos do dique.

\section{PETROGRAFIA E TEXTURA A Fig. 7} mostra a distribuição de amostras selecionadas para cada grupo litológico nos diagramas de classificação modal de rochas ígneas, o QAP e o Q(A+P)M (Streckeisen 1976, Lameyre \& Bowden 1982), sendo $\mathrm{Q}=$ quartzo, $\mathrm{A}=$ feldspato alcalino, feldspato potássico + plagioclásio com $<5 \%$ Anortita, $\mathrm{P}=$ plagioclásio (Anortita $>5 \%$ ), $\mathrm{M}=$ total de minerais máficos. As porcentagens modais foram calculadas

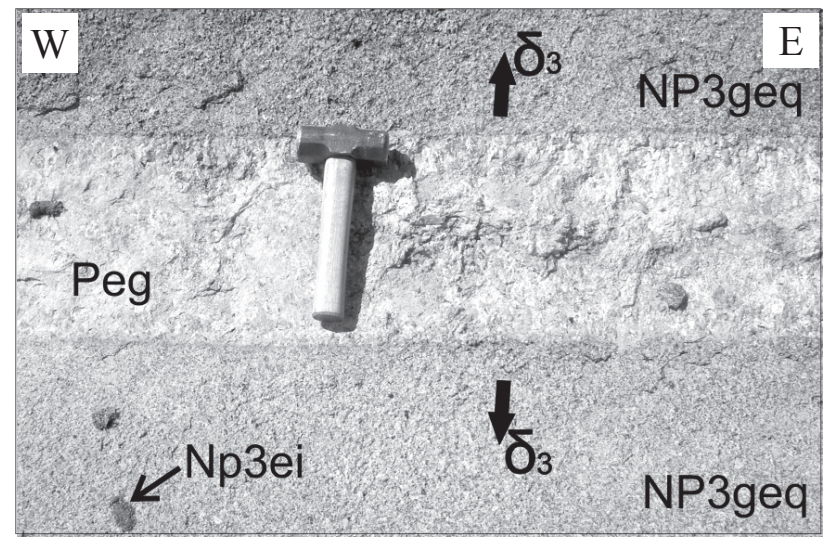

Figura 6 - Dique de pegmatito intrusivo em granito equigranular, na porção Sudeste do pluton, indicando extensão Norte-Sul.

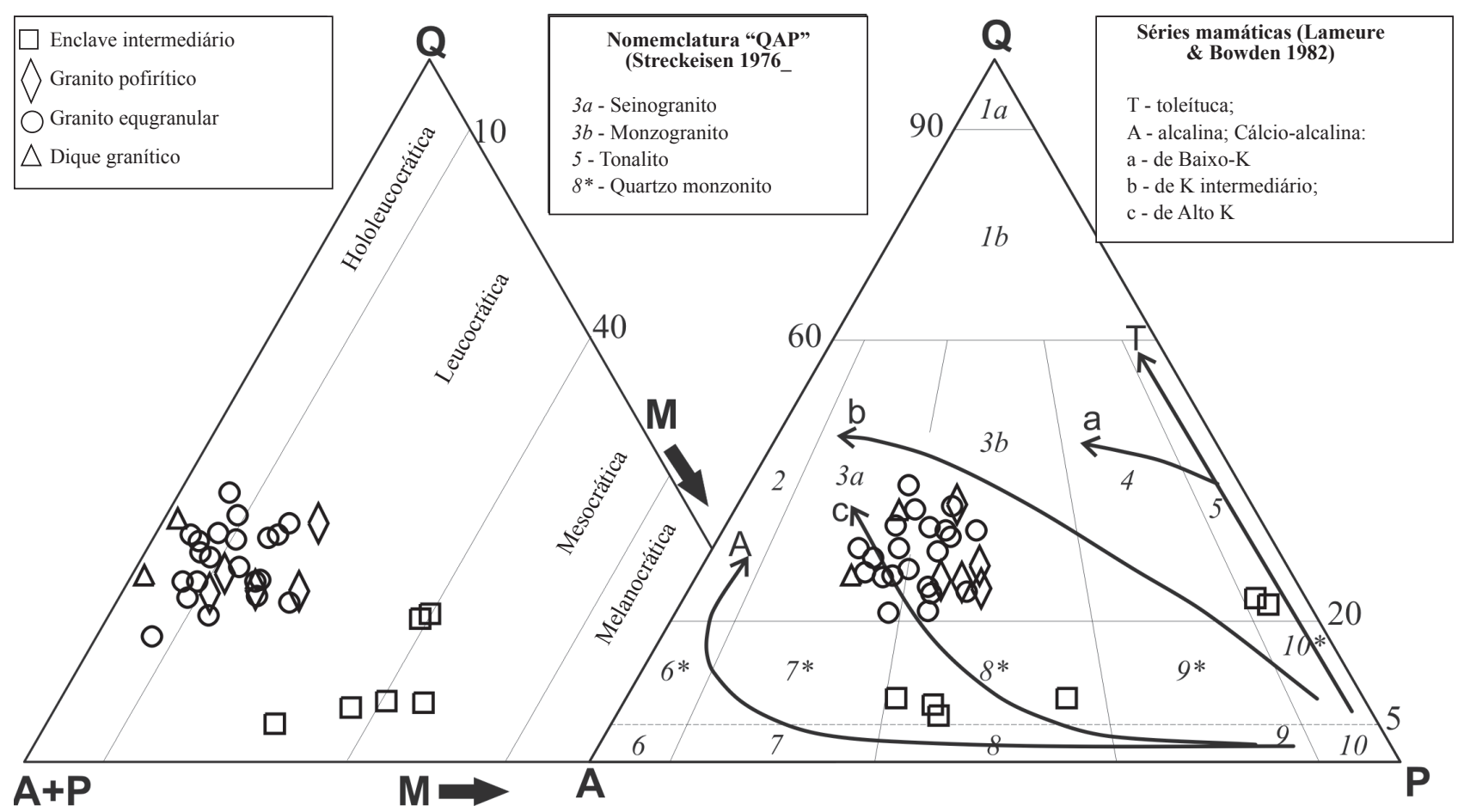

Figura 7 - Classificação das rochas plutônicas estudadas nos diagramas $Q A P$ e $Q(A+P) M$ de Streckeisen (1976), sendo Q: quartzo, A: feldspato alcalino, feldspato potássico + plagioclásio com < 5\% Anortita, P: plagioclásio (Anortita > 5\%), M: total de minerais máficos. 
com a contagem de 1 mil pontos por seção, utilizando um microscópio petrográfico Leica DMLP com contador de pontos eletrônico acoplado, controlado via computador pelo aplicativo Petrog v. $2.45 \mathrm{da}$ Conwy Valley Systems Limitada. Para a classificação dos tipos litológicos foram considerados a composição modal, os aspectos texturais (tamanho e arranjo entre os grãos) e a abundância de minerais máficos. A concentração de minerais máficos (o índice de cor "M") foi usado para classificar as rochas como hololeucocráticas $(\mathrm{M}<10 \%)$, leucocráticas $(\mathrm{M}<40 \%)$ ou mesocráticas $(\mathrm{M}=40-65)$. A estimativa do teor de anortita do plagioclásio (revisão Deer et al. 1983, Hibbard 1995, Nesse 2004) tomou como base o ângulo de extinção em seções perpendiculares ao plano (010) pelo método Michel-Lévy ou, quando da ausência de grãos adequados, o relevo e índice de refração relativo do plagioclásio em contato com quartzo. O litotipo de maior abundância no pluton é o granito equigranular. Os granitos equigranulares, assim como os porfiríticos (de distribuição restrita), são rochas hololeucocráticas a leucocráticas, com microclínio, plagioclásio e quartzo perfazendo a mineralogia principal. A biotita é o mineral máfico dominante, ocorrendo ainda hornblenda, titanita, zircão, apatita, alanita e opacos, e, como minerais secundários, clorita, mica branca e carbonato.

No caso dos enclaves microgranulares de quartzo, monzonito, biotita e hornblenda constituem as fases predominantes (perfazem de 28 a $47 \%$ modal) e definem a orientação principal (Figs. 8A e B). Já nos enclaves de biotita tonalito a hornblenda é ausente, sendo estes compostos essencialmente de biotita (Fig. 9A), plagioclásio, quartzo e microclínio, com quantidades subordinadas de apatita, titanita, zircão e epídoto. As composições modais de cada amostra analisada estão nas Tabs. 2 a 4.

\section{Biotita sienogranito a monzogranito equigranu-}

lar A textura equigranular é observada com cristais subédricos a anédricos de granulação média ou grossa (Fig. 8). O microclínio exibe micropertitas, inclusões esparsas de plagioclásio e alguns cristais com alteração para mica branca fina. O plagioclásio $\left(\mathrm{An}_{20}\right)$ ocorre em grãos anédricos, ameboidais, formando textura mirmequita no contato com microclínio (Fig. 9A), ou como cristais subédricos a anédricos com zonação normal de núcleos mais cálcicos (composição confirmada por microscopia eletrônica de varredura, MEV-EDS), normalmente mais alterados para mica branca (Fig. 10A). Bandas e lamelas de deformação em cristais de quartzo mostram efeito de evento rúptil afetando cristais maiores (Fig. 10B).

A biotita apresenta inclusões de titanita, zircão (por vezes zonado) e apatita com seções basais hexagonais ou retangulares (Fig. 11A) e altera para clorita verde, a qual pode pseudomorfisar totalmente a biotita (Fig. 11B). Já a alanita ocorre com parte central

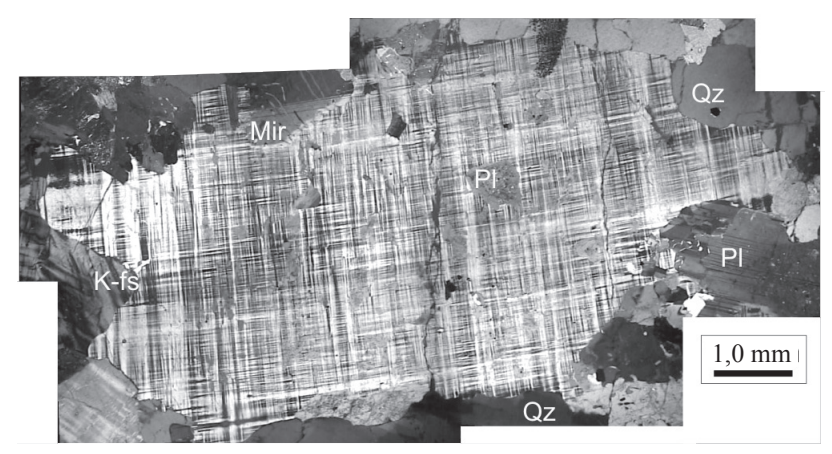

Figura 8 - Fenocristal de microclínio com macla albita-periclina e inclusões de plagioclásio (luz com polarização cruzada).
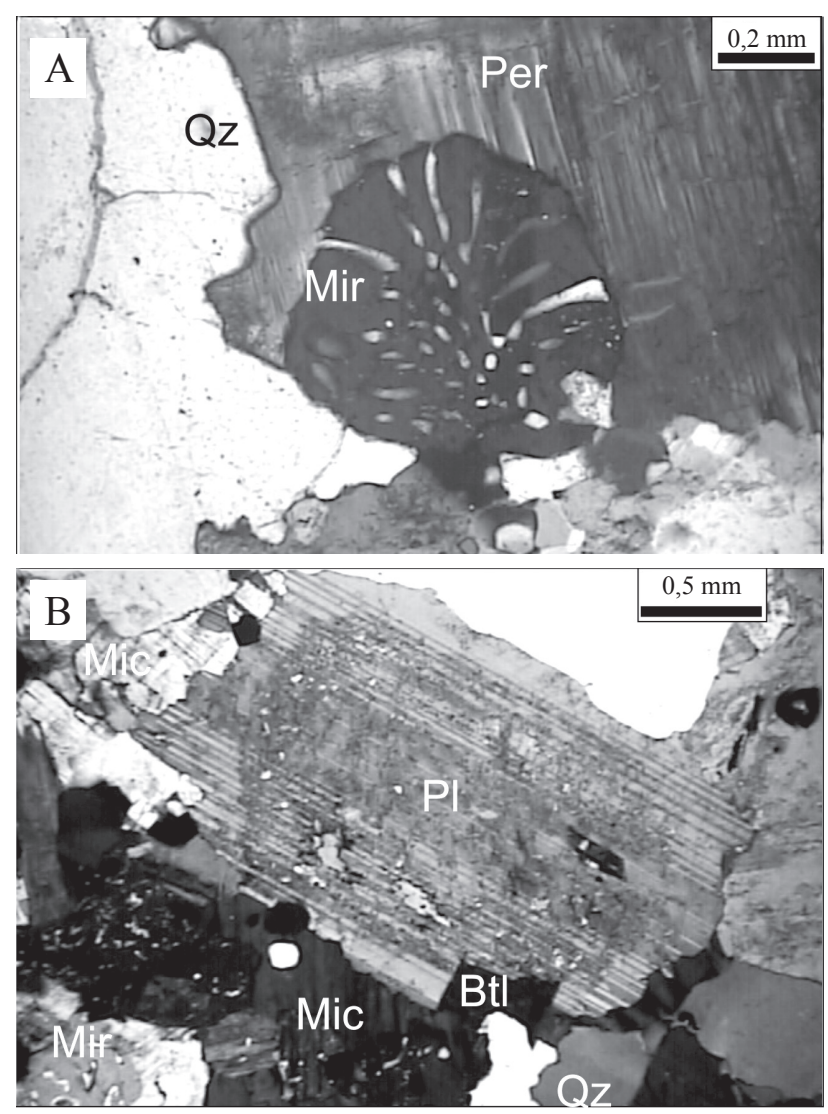

Figura 9 - (A) Texturas pertítica e mirmequítica representando respectivamente processos de exsolução e recristalização tardi-magmática (luz com polarização cruzada - LPC); (B) Plagioclásio com zonação normal evidenciada pela alteração para mica branca e argilominerais na porção central (LPC). 
Tabela 2 - Porcentagem modal para os sienogranitos equigranulares

\begin{tabular}{lcccccccccc}
\hline & \multicolumn{1}{c}{ Sienogranitos equigranulares } \\
\cline { 2 - 12 } & D1 & D2A & D2C & D4B & D13 & D7A & D12B & D31C & D40 & D19A \\
\hline Quartzo & 36,9 & 22,7 & 33,2 & 31,1 & 24,6 & 24,3 & 37,2 & 28,5 & 25,4 & 17 \\
\hline Microclínio & 34,1 & 44,1 & 33,7 & 41,9 & 47,3 & 45,2 & 38,4 & 43,3 & 44 & 49,2 \\
\hline Plagioclásio & 15,1 & 17,1 & 24,2 & 19,4 & 21,5 & 22,1 & 18,4 & 21,3 & 17,8 & 27 \\
\hline Biotita & 12,2 & 12,1 & 7,8 & 4,9 & 3,9 & 7,3 & 1,2 & 1,3 & 10,4 & 1,5 \\
\hline Titanita & 0,1 & 2,1 & 0,1 & 0,6 & 0,7 & - & - & - & 0,5 & 1,6 \\
\hline Zircão & traço & traço & traço & traço & traço & traço & traço & 0,1 & traço & 0,1 \\
\hline Apatita & traço & traço & traço & traço & traço & traço & traço & traço & traço & traço \\
\hline Alanita & 0,2 & 0,6 & 0,1 & 0,1 & 0,6 & traço & traço & traço & 0,4 & 0,5 \\
\hline Opacos & 0,7 & 0,2 & 0,1 & 0,5 & 0,6 & 0,4 & traço & 0,7 & 0,5 & 1 \\
\hline Clorita & 0,6 & 1,0 & 0,5 & 1,4 & 0,5 & 0,6 & 3,2 & 3,9 & 1 & 2 \\
\hline Mica branca & 0,1 & 0,1 & 0,3 & 0,1 & 0,3 & 0,1 & 1,6 & 0,9 & traço & 0,1 \\
\hline Quartzo & 30,5 & 27,1 & 36,4 & 33,7 & 26,3 & 26,5 & 39,6 & 30,6 & 29,1 & 18,2 \\
\hline Feldspato alcalino & 51,6 & 52,5 & 37 & 45,4 & 50,6 & 49,3 & 40,9 & 46,5 & 50,5 & 52,8 \\
\hline Plagioclásio (Anortita & 17,9 & 20,4 & 26,6 & 21 & 23 & 24,1 & 19,6 & 22,9 & 20,4 & 29 \\
\hline 5\%) & 13,9 & 16 & 8,9 & 7,64 & 6,6 & 8,4 & 6 & 6,9 & 12,8 & 6,8 \\
\hline MMáficos & 49,2 & 61,2 & 57,9 & 61,3 & 68,8 & 67,3 & 56,8 & 64,6 & 61,8 & 76,2 \\
\hline A+P & & & & & & & & \\
\hline
\end{tabular}

$\mathrm{TR}=$ porcentagem em traços

Tabela 3 - Porcentagem modal para os monzogranitos equigranulares

\begin{tabular}{|c|c|c|c|c|c|c|c|c|c|c|c|}
\hline & \multicolumn{11}{|c|}{ Monzogranitos equigranulares } \\
\hline & D9B & D11 & D7B & D8B & $\mathrm{D} 18$ & D33A & $\mathrm{D} 47$ & $\mathrm{D} 46$ & D32 & D6 & D29 \\
\hline Quartzo & 28,7 & 31,7 & 27,6 & 30,3 & 29,6 & 23,3 & 18,8 & 20,6 & 30,2 & 18,8 & 22 \\
\hline Microclínio & 35,2 & 34,3 & 38,6 & 37,1 & 35,5 & 39,2 & 41,6 & 37,8 & 35 & 32,2 & 42 \\
\hline Plagioclásio & 21,5 & 29,7 & 25,5 & 26,8 & 24,5 & 21 & 27 & 24,2 & 18,4 & 26,8 & 27,5 \\
\hline Biotita & 9,1 & 4 & 6,8 & 3,2 & 8 & 12 & 11 & 10,5 & 12,4 & 15 & 7,5 \\
\hline Hornblenda & - & - & - & - & - & - & traço & - & traço & 1,0 & - \\
\hline Titanita & 1,7 & TR & - & - & 0,01 & 0,5 & 0,5 & 3 & 0,1 & 1,5 & - \\
\hline Zircão & traço & traço & traço & traço & traço & 0,1 & - & 0,4 & traço & 0,2 & traço \\
\hline Apatita & traço & traço & traço & traço & traço & traço & traço & traço & traço & traço & traço \\
\hline Alanita & 0,4 & 0,1 & traço & traço & traço & 0,5 & 0,2 & 0,4 & 0,4 & 0,5 & - \\
\hline Opacos & 0,1 & 0,1 & traço & 0,2 & 1,0 & 0,3 & 0,3 & 1,0 & 1,5 & 1,0 & traço \\
\hline Clorita & 2,3 & 0,1 & 1,0 & 1,7 & 1,0 & 3,0 & 0,5 & 2,0 & 2,0 & 3,0 & 1,0 \\
\hline Mica branca & 1,0 & traço & 0,5 & 0,7 & 0,4 & 0,1 & 0,1 & 0,1 & traço & 0,05 & traço \\
\hline Quartzo & 33,6 & 33,1 & 30,1 & 32,2 & 33 & 27,9 & 21,5 & 24,9 & 36,1 & 24,2 & 24,0 \\
\hline $\begin{array}{l}\text { Feldspato } \\
\text { alcalino }\end{array}$ & 41,2 & 35,8 & 42,1 & 39,4 & 39,6 & 46,9 & 47,6 & 45,8 & 41,9 & 41,4 & 45,9 \\
\hline $\begin{array}{l}\text { Plagioclásio } \\
(\text { Anortita }>5 \%)\end{array}$ & 25,2 & 31 & 27,8 & 28,5 & 27,3 & 25,1 & 30,9 & 29,3 & 22 & 34,4 & 30,1 \\
\hline$\sum$ Máficos & 14,6 & 4,3 & 8,3 & 5,8 & 10,4 & 16,5 & 12,6 & 17,4 & 16,4 & 24,5 & 8,5 \\
\hline $\mathrm{A}+\mathrm{P}$ & 56,7 & 64 & 64,1 & 63,9 & 60 & 60,2 & 68,6 & 62 & 53,4 & 59,0 & 69,5 \\
\hline
\end{tabular}

metamitizada e borda de epídoto. Localmente, ocorrem cristais reliquiares de hornblenda, de cor verde e tamanho menor que $0,3 \mathrm{~mm}$. A titanita acontece em fenocristais losangulares, euédricos (Fig. 12), podendo conter inclusões de zircão, apatita e opacos. Alguns cristais de titanita de mesma geração apresentam alteração parcial ou total que consiste na transformação da titanita em um material escuro. O processo de alteração da titanita se inicia ao longo das fraturas e clivagem do cristal e vai sendo expandido para todo o cristal, chegando a substituí-lo quase que completamente (Fig. 11B). A alteração da titanita magmática pode ocorrer devido à atuação de fluídos hidrotermais em estágio tardi-magmático gerando clorita e $\mathrm{TiO}_{2} \pm$ quartzo \pm calcita (Morad et al. 2009), ou devido a processos intempéricos, criando pseudomorfos de anatásio (Sígolo \& Boulangé 1990). A microscopia eletrônica de varredura com microanálise pontual por dispersão de energia (MEV-EDS) foi utilizada para obter informações semiquantitativas acerca da composição química de cristais de titanita alterada e preservada. As seções delgadas, inicialmente preparadas sem lamínula no Laboratório de Laminação Petrográfica do Departamento de Geologia da Universidade Federal do Rio Grande do Norte (UFRN), foram analisadas com o microscópio 
Tabela 4-Porcentagem modal para os monzogranitos porfiriticos, enclaves micogranulares e diques graníticos

\begin{tabular}{lccccccccccccc}
\hline & \multicolumn{4}{c}{ Monzogranito porfirítico } & \multicolumn{4}{c}{ Tonalito } & \multicolumn{3}{c}{ Quartzo monzonito } & \multicolumn{2}{c}{ Diques graníticos } \\
\cline { 2 - 15 } & D3 & D5 & D31B & D23 & D41 & D2D & D2E & D19B & D21 & D22 & D31A & D14B & D7C \\
\hline Quartzo & 29 & 22 & 21,4 & 20 & 24,7 & 13 & 13 & 5,0 & 4,0 & 5,3 & 4,8 & 34,2 & 25 \\
\hline Micro-clínio & 29 & 36 & 34,4 & 33,7 & 33,5 & 3,9 & 3,0 & 33,6 & 38,7 & 34 & 19,6 & 43,8 & 53,5 \\
\hline Plagio-clásio & 22 & 33 & 27,4 & 23,5 & 30,3 & 40 & 42 & 24 & 28,8 & 19 & 29 & 20,5 & 20 \\
\hline Biotita & 15 & 4,4 & 13 & 16,5 & 8 & 39,6 & 37,5 & 20 & 15 & 24,5 & 22,3 & traço & traço \\
\hline Horn-blenda & - & - & - & 1,5 & - & - & - & 13,3 & 10,5 & 12,2 & 21,3 & - & - \\
\hline Titanita & 1,8 & 2,2 & 2,0 & 3,0 & 0,4 & 1,5 & 2,5 & 3,7 & 2,9 & 4,5 & 1,7 & - & - \\
\hline Zircão & 0,1 & 0,2 & 0,1 & 0,1 & 0,1 & 0,3 & traço & traço & traço & traço & traço & - & - \\
\hline Apatita & traço & traço & traço & traço & traço & 1,7 & 2,0 & 0,3 & 0,1 & 0,3 & 1,3 & - & - \\
\hline Alanita & 0,1 & 0,1 & 0,3 & 0,2 & 0,2 & - & - & - & - & - & - & - & - \\
\hline Opacos & 1,0 & 0,5 & 0,1 & 0,4 & 0,5 & traço & traço & 0,1 & traço & 0,2 & traço & traço & 1,0 \\
\hline Clorita & 1,6 & 1,2 & 1,3 & 1,0 & 2,0 & - & - & - & - & - & - & - & - \\
\hline $\begin{array}{l}\text { Mica } \\
\text { branca }\end{array}$ & 0,4 & 0,4 & traço & 0,1 & 0,3 & - & - & - & - & - & - & 1,5 & 0,5 \\
\hline Epidoto & - & - & - & - & - & traço & traço & - & - & - & - & - & - \\
\hline Quartzo & 36,3 & 24,2 & 25,7 & 25,9 & 27,9 & 23,4 & 22,4 & 8,0 & 5,6 & 9,1 & 9,0 & 35,0 & 25,4 \\
\hline $\begin{array}{l}\text { Felds-pato } \\
\text { alcalino }\end{array}$ & 36,3 & 39,6 & 41,3 & 43,7 & 37,9 & 6,3 & 5,2 & 53,7 & 54,1 & 58,3 & 36,7 & 44,1 & 54,3 \\
\hline $\begin{array}{l}\text { Plagio-clásio } \\
\text { (An>5\%) }\end{array}$ & 27,5 & 36,3 & 32,9 & 30,4 & 34,2 & 70,3 & 72,4 & 38,3 & 40,3 & 32,6 & 54,3 & 20,9 & 20,3 \\
\hline \begin{tabular}{l} 
MMáfi-cos \\
\hline A+P
\end{tabular} & 20 & 9,0 & 16,8 & 22,8 & 11,5 & 43 & 42 & 37,4 & 29 & 41,7 & 46,6 & 1,5 & 1,5 \\
\hline
\end{tabular}
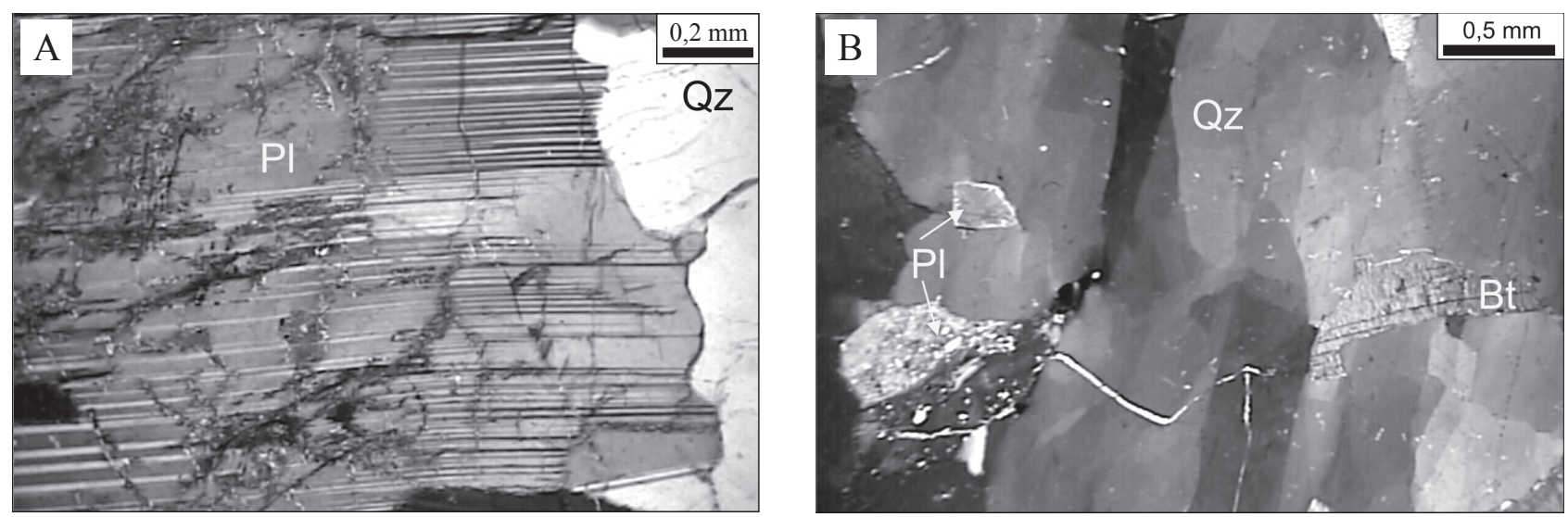

Figura 10 - (A) Deformação mecânica da geminação polissintética em plagioclásio fraturado (luz com polarização cruzada-LPC); (B) Quartzo com bandas e lamelas de deformação e extinção ondulante, contendo inclusões de biotita e plagioclásio alterado (LPC).
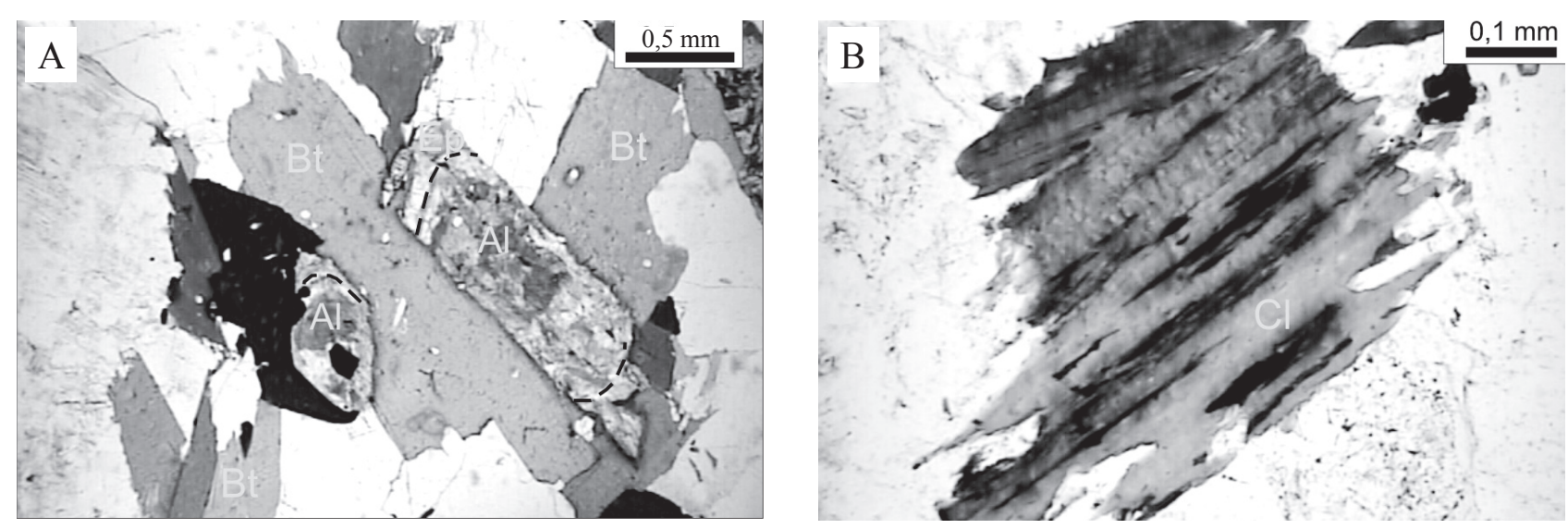

Figura 11 - (A) Alanita metamitizada com bordas de epídoto e alanita zonada (luz plano paralela - LPP); (B) Clorita formada por transformação de biotita em estágio pós-magmático (LPP). 

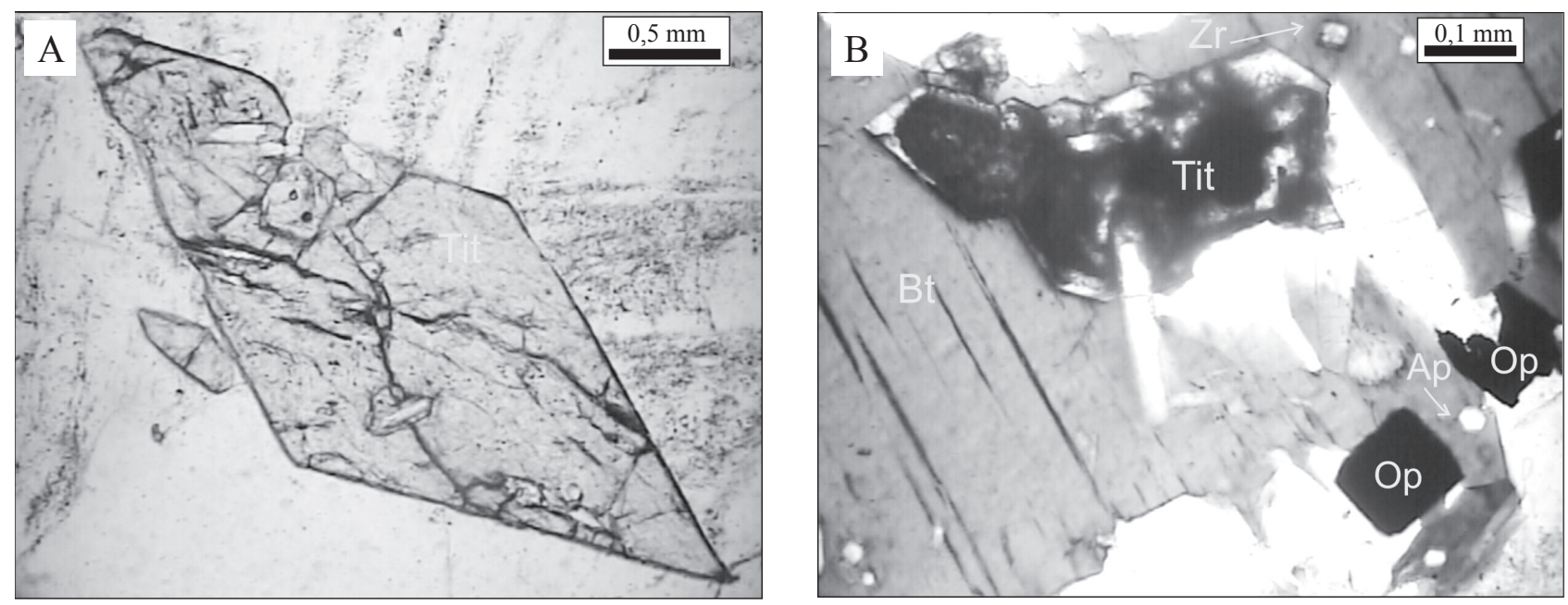

Figura 12 - (A) Cristal euédrico fraturado de titanita (Tit) primária (luz plano paralela - LPP); (B) Titanita alterada para material escuro, além de apatita (Ap), zircão (Zr) e opacos (Op), inclusos em biotita (Bt) (LPP).

Shimadzu SSX-550, no Centro de Tecnologias do Gás e Energias Renováveis do Rio Grande do Norte (CT-GAS-ER/RN), com feixe de elétrons com corrente de $0,33 \mathrm{nA}$, regulada em tensão de $20 \mathrm{kV}$, e tempo de contagem EDS de 45 segundos por análise.

Os dados semiquantitativos não permitiram determinar a natureza do material secundário proveniente da alteração da titanita, uma vez que as variações composicionais não são muito significativas. Estas porções alteradas são levemente enriquecidas em $\mathrm{TiO}_{2}(+2,2 \%)$ e $\mathrm{Fe}_{2} \mathrm{O}_{3}(+1,17 \%)$ e empobrecidas em $\mathrm{CaO}$ (- 3,84\%). Minerais opacos são euédricos a subédricos (primários), atingindo até $0,2 \mathrm{~mm}$ (Fig. 12B) ou anédricos, derivados da alteração de titanita ou desestabilização de biotita. A presença da paragênese titanita + magnetita + quartzo (Fig. 12B) indica condições oxidantes $\operatorname{com} f \mathrm{O}_{2}$ moderada a alta. As porcentagens modais das amostras de sienogranitos e monzogranitos equigranulares são apresentadas respectivamente nas Tabs. 2 e 3.

\section{Biotita Monzogranito Porfirítico A textu-} ra porfirítica é realçada por fenocristais subédricos a anédricos de microclínio $(5 \mathrm{~mm})$, plagioclásio $(4,5 \mathrm{~mm})$, quartzo $(2 \mathrm{a} 4 \mathrm{~mm})$, biotita $(1,5 \mathrm{~mm})$, titanita $(3,5 \mathrm{~mm})$ e alanita $(3 \mathrm{~mm})$, dispostos em uma matriz composta por cristais subédricos a euédricos de quartzo, plagioclásio e microclínio $(<0,5 \mathrm{~mm})$, biotita $(0,2 \mathrm{~mm})$, titanita $(0,3 \mathrm{~mm})$, alanita, zircão $(<0,1 \mathrm{~mm})$, apatita $(<0,1 \mathrm{~mm}) \mathrm{e}$, raramente, hornblenda $(<0,3 \mathrm{~mm})$.

Os fenocristais de microclínio são maclados na lei da albita-periclína e apresentam pertitas finas (Fig. 13A). Os fenocristais de plagioclásio $\left(\mathrm{An}_{20}\right)$ mostram zonação composicional, com núcleos mais alterados para mica branca e bordas límpidas de albita, apresentando inclusões de biotita, quartzo e opacos. Os fenocristais de quartzo contam com extinção

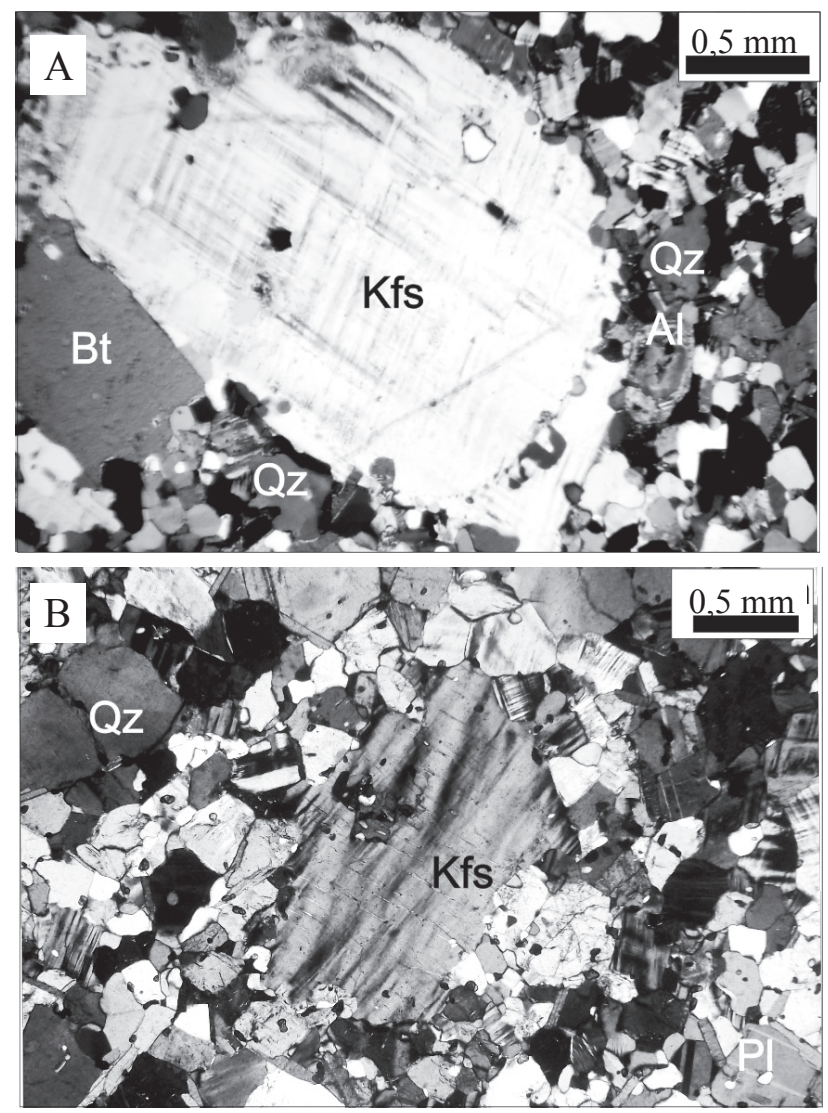

Figura 13 - (A) Fenocristal de microclínio (Kfs) e biotita (Bt) em meio à matriz quartzo-feldspática, destacando-se cristais de quartzo $(Q z)$ com extinção ondulante e alanita (Al) zonada (luz com polarização cruzada - LPC); (B) Detalhe de fenocristal de microclínio extensivamente recristalizado, formando mosaicos poligonais (LPC). 
ondulante, indicando ação de evento rúptil de alto nível crustal (Sibson 1977).

Nas rochas da porção sul do pluton, em que a deformação milonítica é mais intensa, são observados cristais de microclínio, equidimensional, resultantes da recristalização em alta temperatura nas bordas dos fenocristais (Fig. 13B). As lamelas pleocróicas de biotita definem uma leve orientação à rocha e se mostram frequentemente alteradas para clorita verde, podendo conter inclusões de zircão, apatita e opacos. A titanita, por vezes, inclui opacos, biotita e apatita. A alanita apresenta metamitização da porção central e halo pleocróico quando em contato com biotita (Fig. 13A). São observadas exsolução pertítica no K-feldspato e mirmequitização nos contatos com plagioclásio, ambas associadas ao processo de resfriamento do pluton provavelmente, ainda à temperatura relativamente elevada (Vernon 2004). As porcentagens modais das amostras de monzogranitos porfiríticos estão na Tab. 4.

\section{Enclaves microgranulares A quantidade de} fases máficas (subédricas a anédricas) distingue os enclaves das demais rochas, com os primeiros plotando como mesocráticas ou transicionais a leucocráticas (Fig. 7, Tab. 4). O hornblenda-biotita quartzo monzonito é caracterizado pela presença ubíqua de hornblenda e microclínio, com menor proporção de quartzo. $\mathrm{O}$ quartzo forma cristais intersticiais, com extinção ondulante e inclusões de biotita e apatita. No quartzo monzonito, os cristais de quartzo têm entre 0,2 e $1,5 \mathrm{~mm}$, enquanto que nos biotita tonalitos centimétricos ocorrem com tamanho entre 0,1 e $0,5 \mathrm{~mm}$ ou em grãos arredondados de até $1,5 \mathrm{~mm}$ (Fig. 14B). Estes últimos ocorrem de maneira bastante esparsa e poderiam ser interpretados como ocelos desenvolvidos em contexto de mistura de magmas, em que o quartzo (polo félsico) é parcialmente dissolvido com a mudança na composição do magma e, ao mesmo tempo, é iniciada a cristalização de minerais máficos ao redor, gerando bordas tardias.

Porém, no caso estudado, o quartzo não apresenta manteamento máfico característico, ocorrendo, inclusive, cristalização de grãos de plagioclásio nas bordas tardias, o que permite a interpretação de que os mesmos podem ser cristais de quartzo com textura poiquilítica (poiquilomosáico de Vernon 1991). O plagioclásio ( 0,2 a $1 \mathrm{~mm} ; \mathrm{An}_{25}$ ) ocorre com geminação polissintética segundo a lei da albita e inclusões de apatita e biotita. No tonalito, alguns cristais apresentam extinção ondulante da macla polissintética, indicando a ação de deformação rúptil tardia. O microclínio $(0,2$ a $0,4 \mathrm{~mm})$ tem geminação polissintética na lei da albita-periclina. A biotita $(0,08$ a $1 \mathrm{~mm})$ define lamelas com forte pleocroísmo marrom ou verde. A hornblenda $(0,1 \mathrm{a} 2,3 \mathrm{~mm})$ ocorre na forma de cristais verde a marrom escuros. A titanita $(0,1$ e $0,8 \mathrm{~mm})$ forma cristais anédricos, cujas relações de contato indicam formação a partir da desestabilização de biotita e hornblenda (Fig. 15B). A apatita (até $0,3 \mathrm{~mm}$ ) é alongada ou acicular, incluída em quartzo, feldspatos, biotita, hornblenda e titanita, sendo a sua presença mais abundante nos tonalitos. O zircão $(<0,05 \mathrm{~mm})$ ocorre incluso na biotita. Os minerais opacos são anédricos, comumente associados à desestabilização de biotita, hornblenda e titanita (Figs. 15A e B). Grânulos de epídoto $(<0,05 \mathrm{~mm})$ encontram-se como produto de alteração de plagioclásio.

Dique de sienogranito fino a médio As duas amostras analisadas mostram composição mineralógica similar, porém com diferenças relevantes nas
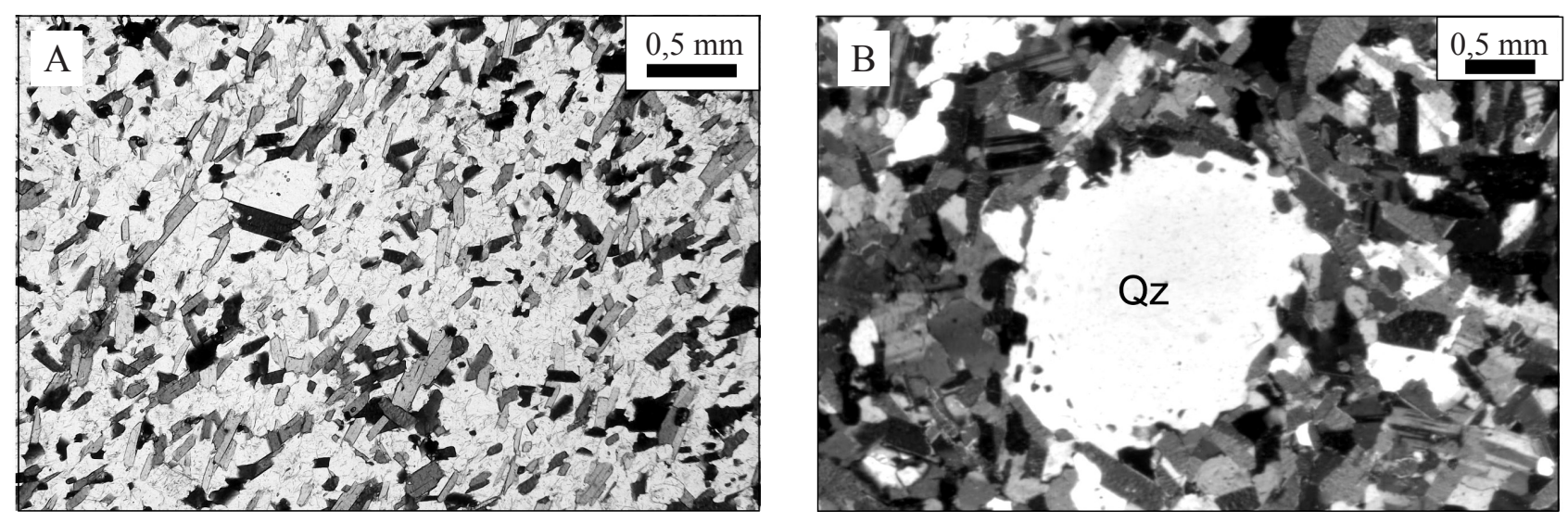

Figura 14 - (A) Textura equigranular de tonalito, mostrando orientação de lamelas de biotita (luz plano paralela - LPP); (B) Megacristal de quartzo ( $Q z)$, com borda de quartzo tardi-magmática englobando pequenos grãos de plagioclásio e biotita (luz com polarização cruzada - LPC). 
proporções modais (Tab. 4). A amostra D-14 (porção Nordeste da área) tem maior proporção de quartzo e menor de K-feldspato, apresenta alteração de feldspatos mais intensa e textura granofírica, que não foi observada na amostra D7C. A textura granofírica (Fig. 16A), típica dos granitos de nível crustal mais rasos (Coleman et al. 1992, Nascimento et al. 2002), evidencia que o magma gerador destas rochas teve evolução ou fonte distinta das demais unidades do pluton. A mineralogia essencial é representada por cristais subédricos a anédricos de microclínio $(0,4 \mathrm{a}$ $3 \mathrm{~mm})$, plagioclásio $(0,3$ a $1,5 \mathrm{~mm})$ e quartzo $(0,2$ e $2 \mathrm{~mm}$ ), ocorrendo também mica branca relacionada a processos de alteração dos feldspatos e biotita, além de raros cristais de biotita $(<0,1 \mathrm{~mm})$ alterada e minerais opacos $(0,04$ a $0,5 \mathrm{~mm})$. O microclínio em geral mostra textura micropertítica e geminação do tipo albita-periclínio. O plagioclásio $\left(\mathrm{An}_{21}\right)$ ocorre por vezes com zonação química e textura mirmequítica (Fig. 16B). O processo de alteração tardia pós-magmática é intenso, levando à formação de mica branca. A forma e o modo de ocorrência dos minerais opacos permitem interpretar que eles são produto de oxidação em etapa tardi-magmática.

DISCUSSÕES Relações de contato entre as rochas que compõem o pluton Serra da Macambira indicam a estratigrafia magmática relativa, iniciando com enclaves intermediários (quartzo-monzonitos e biotita tonalitos), seguindo com biotita-monzogranitos porfiríticos e biotita-granitos equigranulares, e finalizando com diques graníticos e pegmatíticos. A ocorrência dos quartzo monzonitos é restrita à borda sul do pluton, enquanto que os biotita tonalitos centimétricos ocorrem em todo o pluton em granitos equigranulares e porfiríticos. Ambos têm biotita como máfico principal, porém apenas os quartzo monzoníticos apresentam hornblenda.

Os granitos porfiríticos mostram evidências de coexistência entre um magma granítico e outro diorítico ou gabróide. De acordo com Didier et al. (1982) e Vernon (1984), a maioria dos enclaves máficos em rochas graníticas corresponde a pulsos de magma injetados e aprisionados no hospedeiro granítico.
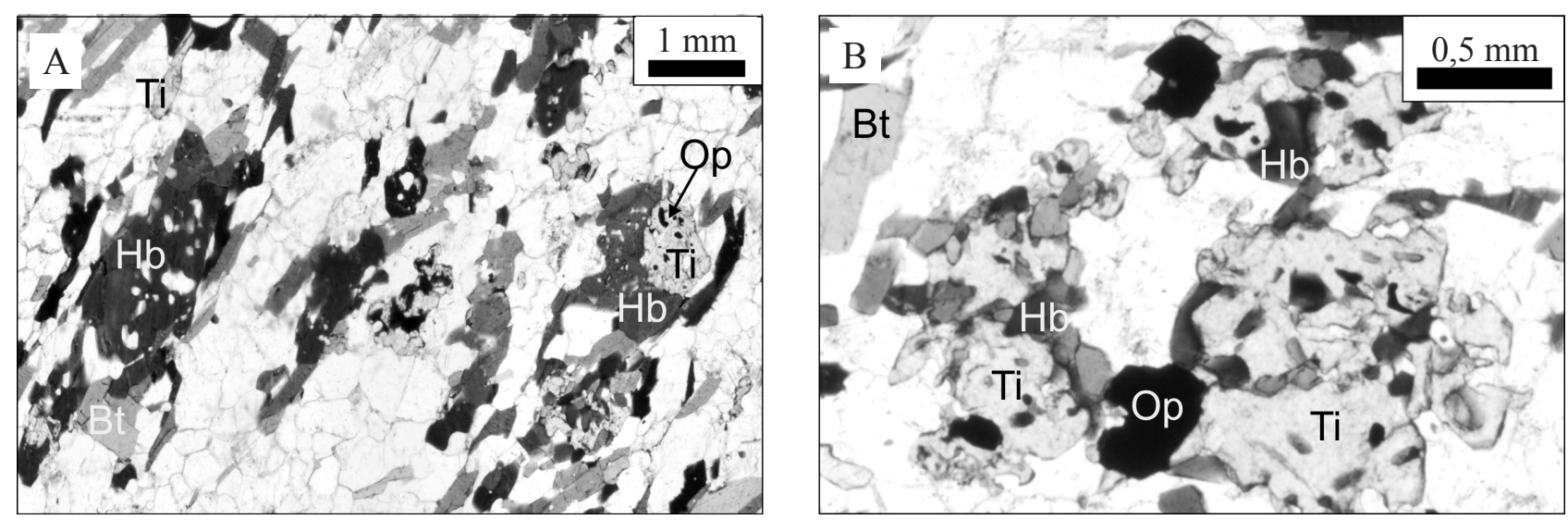

Figura 15 - (A) Hornblenda (Hb), biotita (Bt), titanita (Ti) e minerais opacos (Op) em quartzo monzonitos situados na porção Sudoeste do pluton (luz plano paralela-LPP); (B) Titanita tardi-magmática englobando hornblenda e biotita (LPP).
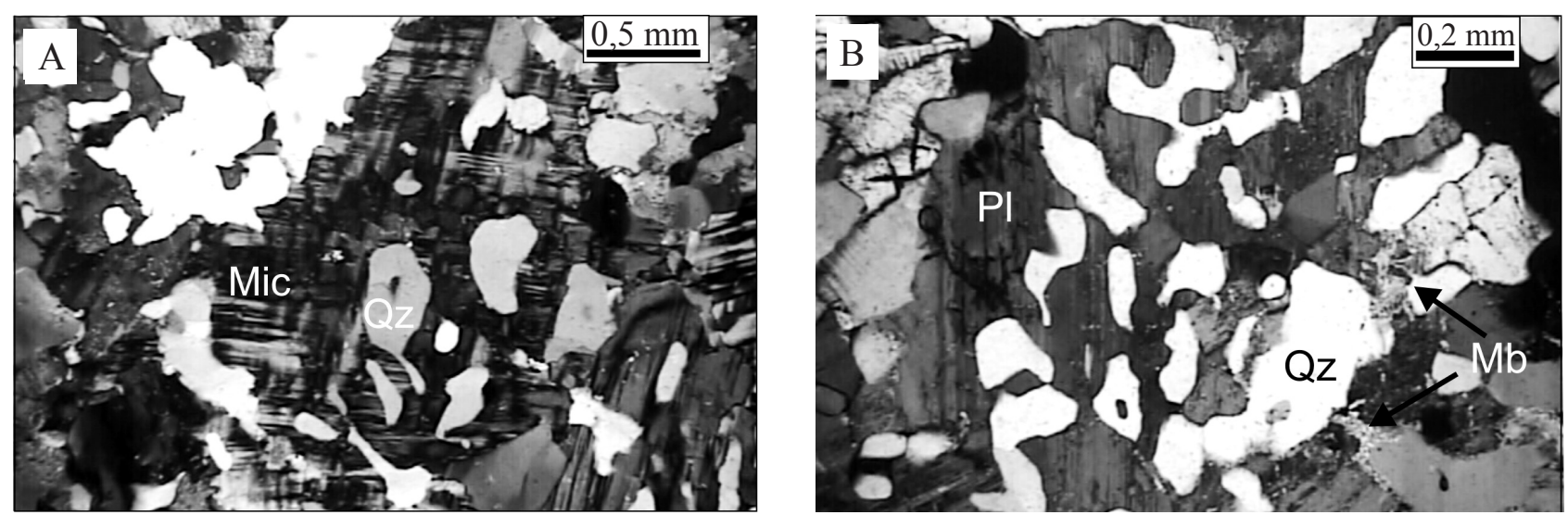

Figura 16- (A) Textura granofírica indicando cristalização dos diques graníticos em condições hipabissais, diferentemente dos demais granitos no pluton (luz com polarização cruzada-LPC); (B) Intercrescimento de quartzo e plagioclásio formando textura mirmequítica (LPC). 
Segundo Whalen \& Currie (1984), zonas de cisalhamento são os sítios mais favoráveis para a coexistência em grande escala de líquidos de composições contrastantes. Magmas ocupam locais de extensão em zonas de cisalhamento e são expelidos em zonas de compressão, no mecanismo conhecido como bombeamento transcorrente dilatante (Brown 1994). Líquidos máficos a intermediários intrudidos em magmas félsicos, mais frios e em processo de cristalização (revisão em Bonin 2004, e Janoušek et al. 2004, e referências por eles citadas), resultando em misturas do tipo mixing e mingling. Esta poderia ser uma explicação para a associação de rochas observadas. Na borda sul do pluton, mosaicos poligonais de microclínio em zona de cisalhamento transcorrente dextrógira evidenciam recristalização em alta temperatura no estágio subsolidus. Estes locais teriam canalizado magmas gerados em maiores profundidades para a câmara magmática onde o magma granítico estava alojado. Em etapa posterior, sob condições de menores temperatura e pressão, tem-se o registro de deformação da macla polissintética em plagioclásio e extinção ondulante em quartzo.

A cristalização de fases minerais hidratadas como anfibólio e biotita, ainda em etapas precoces de diferenciação magmática, indica que os magmas geradores das rochas em tela eram subsaturados em água. Alta pressão parcial de água também é corroborada por texturas pertíticas, que ocorrem abaixo da curva de solvus no sistema ortoclásio-albita (revisão em Winter 2001). A presença da associação titanita + magnetita + quartzo é indicativa de $f \mathrm{O}_{2}$ moderada, corroborada pela ocorrência de epídoto nas bordas de cristais de alanita (Wones 1989). Estas características são também descritas por diversos autores em outros plutons neoproterozoicos na Faixa Seridó (Sial 1986; Nascimento et al. 2003; Medeiros et al. 2007).

A ausência de tramas tectônicas expressivas, exceto a recristalização no estado sólido em zonas de cisalhamento nas bordas do pluton e a linhagem de diferenciação monzonítica ou cálcio-alcalina de alto-K segundo Lameyre \& Bowden (1982), com associação de rochas máficas a intermediárias (os enclaves microgranulares) e ácidas, são coerentes com suítes magmáticas pós-colisionais a pós-orogênicas (Bonin 2004). Embora as características também sejam observadas em granitos sin-orogênicos da Província Borborema (Mariano \& Sial 1990), as feições estruturais e relações de contato com as unidades encaixantes são claramente distintas. $\mathrm{O}$ tipo de enclave e as composições modais das rochas encontradas no pluton Serra da Macambira sugerem derivação a partir de fusão de rocha ígnea crustal, o tipo CI, de Didier et al. (1982).

Diques graníticos e pegmatíticos tardios, intrusivos nas litologias prévias do pluton, caracterizam episódios de nível crustal relativamente elevado, quando então ocorreu o resfriamento final do pluton. A composição mineral e a presença da textura granofírica nestes diques indicam que a cristalização do magma residual foi relativamente rápida em nível crustal raso, hipabissal (Barker 1970, Smith 1974, Nascimento et al. 2002). Datações U-Pb em monazitas de pegmatitos similares em outras porções da Faixa Seridó indicaram idades de 528-520 milhões de anos (Ma) (Baumgartner et al. 2006). Estas idades são cerca de 50 Ma mais jovens do que os granitos volumetricamente dominantes da região e correlatos geologicamente ao corpo Serra da Macambira e 20 - 14 Ma mais novos do que granitos peraluminosos presentes na região (referências na Tab. 1).

CONCLUSÕES Relações de campo, análise petrográfica e textural e integração no contexto regional sugerem as seguintes conclusões sobre o pluton Serra da Macambira:

- pluton é intrusivo em rochas gnássico-migmatíticas paleoproterozoicas (o Complexo Caicó) e metassupracrustais neoproterozoicas (o Grupo Seridó);

- ele se compõe predominantemente de biotita-sienogranitos e biotita-monzogranitos, associados com enclaves microgranulares de hornblenda-biotita quartzo monzonito e biotita tonalito; ocorrendo ainda diques graníticos e pegmatíticos tardios;

- $\quad$ as estruturas observadas se restringem a tramas magmáticas (orientação de feldspatos, quartzo e biotita) no interior do pluton e a milonitos na borda sul, associados a zonas de cisalhamento de alta temperatura;

- $\quad$ as associações minerais encontradas permitem inferir condições de subsaturação em água e fugacidade de oxigênio intermediária para o magma progenitor. Este líquido hidratado teria evoluído, segundo a tendência cálcio-alcalina de alto potássio (série monzonítica);

- em um estágio tardi-magmático houve atuação de fluídos que permitiram a transformação de biotita em clorita e opacos, além da formação 
de mica branca + carbonato ou argilominerais a partir da transformação de feldspatos. Neste mesmo estágio houve recristalização, gerando textura mirmequítica e exsolução e criando textura pertítica, ambas comuns nos granitos porfiríticos e equigranulares, porém não observadas em enclaves intermediários. A microtextura granofírica foi verificada apenas em diques graníticos tardios, indicando cristalização destes em profundidades hipabissais e contribuindo com a interpretação de que os diques não estão relacionados ao magmatismo principal que gerou o pluton;

- as características de campo e petrográficas descritas são similares às observadas em suítes magmáticas pós-colisionais a pós-orogênicas, provavelmente derivadas de fusão de rochas ígneas.

AGRADECIMENTOS Os autores agradecem ao Programa de Pesquisa e Pós-Graduação em Geodinâmica e Geofísica (PPGG) da UFRN pelo apoio logístico e à Coordenação de Aperfeiçoamento de Pessoal de Nível Superior (CAPES) pela bolsa de Mestrado concedida. A dissertação teve apoio do projeto "Magmatismo Pré-Cambriano no Maciço São José de Campestre, NE do Brasil - Litogeoquímica e Anatexia Experimental" (CNPq 479762/2008-2, coordenado por Zorano S. Souza). Agradecemos também aos revisores anônimos pelas excelentes sugestões, que permitiram aperfeiçoar o conteúdo e a redação do texto final.

\section{Referências}

Almeida F.F.M., Hasui Y., Brito Neves B.B., Fuck R.A. 1981. Brazilian structural provinces: an introduction. Earth-Science Reviews, 17:1-29.

Angelim L.A.A., Nesi J.R., Torres H.H.F., Medeiros V.C., Santos C.A., Veiga Junior. J.P., et al. 2006. Geologia e recursos minerais do Estado do Rio Grande do Norte - Escala 1:500.000. Recife, CPRM - Serviço Geológico do Brasil, 119 p.

Barker D.S. 1970. Composition of granophyre, myrmekite and graphic granite. Geological Society of America Bulletin, 81:3339-3350.

Baumgartner R., Romer R.L., Moritz R., Sallet R, Chiaradia M. 2006. Columbite-tantalite-bearing granitic pegmatites from the Seridó Belt, northeastern Brazil: genetic constraints from $\mathrm{U}-\mathrm{Pb}$ dating and $\mathrm{Pb}$ isotopes. The Canadian Mineralogist, 44:69-86.

Bonin B. 2004. Do coeval mafic and felsic magmas in post-collisional to within-plate regimes necessarily imply two contrasting, mantle and crustal, sources? A review. Lithos, 78:1-24.

Brown M. 1994. The generation, segregation, ascent and emplacement of granite magma: the migmatiteto-crustally-derived granite connection in thickened orogens. Earth Science Reviews, 36:83-130.

Coleman R.G., DeBari S., Peterman Z. 1992. A-type granite and the Red Sea opening. Tectonophysics, 204:27-40.

Deer W.A., Howie R.A., Zussman J. 1983. An introduction to the rock-forming minerals. Logman, Harlow, $528 \mathrm{p}$.

Didier J. \& Barbarin B. 1991. The different types of enclaves in granites: Nomenclature. In: Didier J. \& Barbarin B. (eds.) Enclaves in granite petrology. Amsterdam, Elsevier, p. 19-23.

Didier J., Duthou J.L., Lameyre J. 1982. Mantle and crustal granites: genetic classification of orogenic granites and the nature of their enclaves. Journal of Volcanology and Geothermal Research, 14:125-132.

Hibbard M.J. 1995. Petrography to petrogenesis. New Jersey, Prentice Hall, 587 p.

Janoušek V., Braithwaite C.J.R., Bowes D.R., Gerdes A. 2004. Magma-mixing in the genesis of Hercynian calc-alkaline granitoids: an integrated petrographic and geochemical study of the Sázava intrusion, Central Bohemian Pluton, Czech Republic. Lithos, 78:67-99.

Jardim de Sá E.F. 1994. A Faixa Seridó (Província Borborema, NE do Brasil) e o seu significado geodinâmico na cadeia Brasiliana/Pan-Africana. Tese de Doutorado. Universidade de Brasília. Brasília, 803 p.

Lameyre J. \& Bowden P. 1982. Plutonic rock type series: discrimination of various granitoid series and related rocks. Journal of Volcanology and Geothermal Research, 14:169-186.

Legrand J.M., Deutsch S., Souza L.C. 1991. Datação U/ $\mathrm{Pb}$ e granitogênese do Maciço de Acari-RN. In: SBG/ Núcleo Nordeste. Simpósio de Geologia do Nordeste, 15, Recife, Boletim 12, p. 172-174.

Leterrier J., Jardim de Sá E.F., Bertrand J.M., Pin C. 1994. Ages U-Pb sur zircon de granitoides "brasilianos" de la ceinture du Seridó (Province Borborema, NE Brésil). Comptes Rendus des Académies des Sciences, 318:1505-1511.

London, D. 2009. The origin of primary textures in granitic pegmatites. The Canadian Mineralogist, 47(4):697-724.

MacKenzie W.S., Donaldson C.H., Guilford C. 1982. Atlas of igneous rocks and their textures. New York, John Wiley \& Sons, 148 p.

Mariano G. \& Sial A.N. 1990. Coexistence and mixing of magmas in the late precambrian Itaporanga Batholith, state of Paraíba, Northeastern Brazil. Revista Brasileira de Geociências, 20:101-110. 
McReath I., Galindo A.C., Dall'Agnol R. 2002. The umarizal igneous association, Borborema Province, NE Brazil: implications for the genesis of a-type granites. Gondwana Research, 5(2):339-353.

Medeiros V.C., Galindo A.C., Nascimento M.A.L., Freire A.G. 2007. Geologia, petrografia e idade do Batólito de Catolé do Rocha (RN-PB), porção W do Domínio Rio Grande do Norte da Província Borborema. Revista de Geologia, 20:219-230.

Morad S., El-Ghali M.A.K., Caja M.A., Al-Ramadan K., Mansurbeg H. 2009. Hydrothermal alteration of magmatic titanite: evidence from proterozoic granitic rocks, southeastern Sweden. The Canadian Mineralogist, 47(4):801-811.

Nabelek P.I., WhittingtonA.G., Sirbescu M.-L.C. 2010. The role of $\mathrm{H}_{2} \mathrm{O}$ in rapid emplacement and crystallization of granitic pegmatites: resolving the paradox of large crystals in highly undercooled melts. Contributions to Mineralogy and Petrology, 160(3):313-325.

Nascimento M.A.L., Galindo A.C., Souza Z.S. 2002. Textura granofírica nas rochas do granito do Cabo de Santo Agostinho, Província Magmática do Cabo, Bacia de Pernambuco (Nordeste do Brasil): implicações geodinâmicas. Revista de Geologia, 15:101-107.

Nascimento M.A.L., Medeiros V.C., Galindo A.C. 2008. Magmatismo ediacarano a cambriano no domínio Rio Grande do Norte, Província Borborema, NE do Brasil. Estudos Geológicos, 18:4-29. Nascimento M.A.L., Souza Z.S., Hollanda M.H.B.M., Pimentel M.M., Macedo M.H.F., Nascimento R.S.C., et al. 2001. Geocronologia e assinatura isotópica $\mathrm{Rb}-\mathrm{Sr}$ e $\mathrm{Sm}-\mathrm{Nd}$ do magmatismo alcalino neoproterozóico no Maciço São José de Campestre, Nordeste da Província Borborema (NE do Brasil). Estudos Geológicos, 11:67-79.

Nascimento M.A.L., Souza Z.S,. Nascimento R.S.C., Galindo A.C. 2003. Química mineral e evolução petrológica do magmatismo alcalino neoproterozóico do Maciço São José de Campestre. Revista de Geologia, 15:101-107.

Nesse W.D. 2004. Introduction to optical mineralogy. New York, Oxford University Press, 348 p.

Sial A.N. 1986. Granite-types in Northeast Brazil: current knowledge. Revista Brasileira de Geociências, 16:54-72.

Sibson R.H. 1977. Fault rocks and fault mechanisms. Journal of Geological Society, 133(3):191-213.

Sígolo J.B. \& Boulange B.J. 1990. A alteração química e morfológica da titanita em perfil de alteração de nefelina sienitos do Maciço Alcalino de Passa Quatro - MG. Boletim do Instituto de Geologia da USP, Série Cientifica, 21:21-34.

Smith J.V. 1974. Feldspar minerals. Chemical and textural properties. New York, Springer-Verlag, 690 p.

Souza Z.S., Vasconcelos P.M.P., Nascimento M.A.L., Silveira F.V., Paiva H.S., Dias L.G.S., et al. 2003. 40Ar/39Ar geochronology of Mesozoic and Cenozoic magmatism in NE Brazil. In: IV South American Symposium on Isotope Geology, Salvador, Short Papers, v. 2, p. 691-694.
Souza Z.S., Vasconcelos P.M., Nascimento M.A.L., Silveira F.V., Paiva H.S., Dias L.G.S., et al. 2004. Geocronologia e geoquímica do magmatismo Cretáceo a Terciário no nordeste do Brasil. In: $42^{\circ}$ Congresso Brasileiro de Geologia, Araxá, Abstracts CD-Rom.

Souza Z.S., Xiaodong D., Li J.W., Dantas E.L., Galindo A.C. 2010. Multiple late-Neoproterozoic intrusions in the Seridó Domain, NE Brazil. In: $45^{\circ}$ Congresso Brasileiro de Geologia, Belém, Resumo, p. 90-90.

Streckeisen A.L. 1976. To each plutonic rock its proper name. Earth Science Reviews, 12:1-33.

Thomas R. \& Davidson P. 2012. Water in granite and pegmatite-forming melts. Ore Geology Reviews, 46:32-46.

Trindade R.I. 1999. Magnetismo de corpos graniticos e a evolução tectônica brasiliana da porção ocidental da Faixa Seridó (NE do Brasil). Tese de Doutorado, Instituto de Geofísica, Universidade de São Paulo, São Paulo, 184 p.

Trindade R.I., Dantas E.L., Babinski M., Schmus W.R.V. 1999. Short-lived granitic magmatism along shear zone: evidence from $\mathrm{U}-\mathrm{Pb}$ zircon and sphene age of Caraúbas and Tourão granite. In: South American Symposium on Isotope Geology, 2, Actas, p. 143-144.

Van Schmus W.R., Brito Neves B.B., Williams I.S., Hackspacher P.C., Fetter A.H., Dantas E.L., et al. 2003. The Seridó Group of NE Brazil, a late Neoproterozoic pre- to syn- collisional basin in west Gondwana: insights from SHRIMP U-Pb detrital zircon ages and Sm-Nd crustal residence (TDM) ages. Precambrian Research, 127(4):284-327.

Vernon R.H. 1984. Microgranitoid enclaves in granitesglobules of hybrid magma quenched in a plutonic environment. Nature, 309:438-439.

Vernon R.H. 1991. Interpretation of microstructures of microgranitoid enclaves. In: Didier J. \& Barbarin B. (eds) Enclaves and granite petrology. Amsterdam, Elsevier, p.277-291.

Vernon R.H. 2004. A practical guide to rock microstructure. Cambridge, Cambridge University Press, 594 p.

Weinberg R.F., Sial A.N., Mariano G. 2004. Close spatial relationship between plutons and shear zones. Geology, 32:377-380.

Whalen J.B., Currie K.L. 1984. The Topsails igneous terrane, Western Newfoundland: evidence for magma mixing. Contributions to Mineralogy and Petrology, 87:319-327.

Winter J.D. 2001. An introduction to igneous and metamorphic petrology. London, Prentice Hall, 697 p.

Wones D.R. 1989. Significance of the assemblage titanite + magnetite + quartz in granitic rocks. American Mineralogist, 74:744-749.

Young D.A. 2003. Mind over magma: the story of igneous petrology. New Jersey, Princeton University Press, 686 p.

Manuscrito ID 21460

Recebido em: 04/05/2011

Aprovado em: 13/09/2012 